\title{
Secondary organic aerosol in the global aerosol - chemical transport model Oslo CTM2
}

\author{
C. R. Hoyle, T. Berntsen, G. Myhre, and I. S. A. Isaksen \\ Department of Geosciences, University of Oslo, Norway \\ Received: 15 June 2007 - Published in Atmos. Chem. Phys. Discuss.: 26 June 2007 \\ Revised: 18 October 2007 - Accepted: 1 November 2007 - Published: 16 November 2007
}

\begin{abstract}
The global chemical transport model Oslo CTM2 has been extended to include the formation, transport and deposition of secondary organic aerosol (SOA). Precursor hydrocarbons which are oxidised to form condensible species include both biogenic species such as terpenes and isoprene, as well as species emitted predominantly by anthropogenic activities (toluene, m-xylene, methylbenzene and other aromatics). A model simulation for 2004 gives an annual global SOA production of approximately $55 \mathrm{Tg}$. Of this total, $2.5 \mathrm{Tg}$ is found to consist of the oxidation products of anthropogenically emitted hydrocarbons, and about $15 \mathrm{Tg}$ is formed by the oxidation products of isoprene. The global production of SOA is increased to about $69 \mathrm{Tg} \mathrm{yr}^{-1}$ by allowing semivolatile species to partition to ammonium sulphate aerosol. This brings modelled organic aerosol values closer to those observed, however observations in Europe remain significantly underestimated. Allowing SOA to partition into ammonium sulphate aerosol increases the contribution of anthropogenic SOA from about $4.5 \%$ to $9.4 \%$ of the total production. Total modelled organic aerosol (OA) values are found to represent a lower fraction of the measured values in winter (when primary organic aerosol (POA) is the dominant OA component) than in summer, which may be an indication that estimates of POA emissions are too low. Additionally, for measurement stations where the summer OA values are higher than in winter, the model generally underestimates the increase in summertime OA. In order to correctly model the observed increase in OA in summer, additional SOA sources or formation mechanisms may be necessary. The importance of $\mathrm{NO}_{3}$ as an oxidant of SOA precursors is found to vary regionally, causing up to 50\%-60\% of the total amount of SOA near the surface in polluted regions and less than $25 \%$ in more remote areas, if the yield of condensible oxidation products for $\beta$-pinene is used for $\mathrm{NO}_{3}$ oxidation of all ter-
\end{abstract}

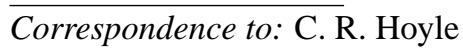

(c.r.hoyle@geo.uio.no) penes. Reducing the yield for $\alpha$-pinene and limonene oxidation in line with recent measurements reduces the global fraction of SOA formed from $\mathrm{NO}_{3}$ oxidation products from $27 \%$ to about $21 \%$. This study underscores the need for SOA to be represented in a more realistic way in global aerosol models in order to better reproduce observations of organic aerosol burdens in industrialised and biomass burning regions.

\section{Introduction}

The study of atmospheric aerosol is important for many reasons, ranging from its impact on human health, to its influences on atmospheric chemistry and climate.

Organic matter makes up a significant portion of the global aerosol burden, accounting for around $20-50 \%$ of total fine aerosol mass at continental mid latitudes, with a contribution of up to $90 \%$ in tropical forested areas (Kanakidou et al., 2005). This organic aerosol can be emitted directly into the atmosphere through processes such as biomass or fossil fuel burning, and aerosol emitted in this manner is termed primary organic aerosol (POA). In addition, organic species that are emitted as volatile gases (VOC) may undergo oxidation reactions to form substances with lower vapour pressures, which subsequently condense to form secondary organic aerosol (SOA).

While black carbon (BC) aerosol absorbs solar radiation and generally leads to a warming of the Earth's atmosphere (Haywood and Shine, 1995; Penner et al., 1998; Schulz et al., 2006), the direct radiative effect of organic carbon (OC) aerosol is negative (Liousse et al., 1996; Cooke et al., 1999; Schulz et al., 2006). In addition to the direct effect on the Earth's radiation balance, carbonaceous aerosols can influence the formation, lifetime and radiative properties of clouds. This may occur through aerosol either causing a modification in the temperature profile of the atmosphere (Hansen et al., 1997; Ackerman et al., 2000), or serving as

Published by Copernicus Publications on behalf of the European Geosciences Union. 
cloud condensation nuclei and directly influencing the number and size of cloud particles as well as the lifetimes of clouds (Twomey, 1959, 1977; Albrecht, 1989).

Apart from the climatic effects of SOA, effects upon human health may also be significant as particulate matter is known to exacerbate respiratory illnesses and generally increase mortality (Ostro and Chestnut, 1998; Jones, 1999).

Under certain conditions, SOA may form the majority of the organic aerosol (Tsigaridis and Kanakidou, 2003; Pun et al., 2003; Zhang et al., 2005; Volkamer et al., 2006; Robinson et al., 2007), therefore an accurate representation in global models is necessary if these are to be used to calculate the climatic effects of organic aerosol. The inclusion of SOA is also important for comparisons of modelled aerosol optical depth with that measured from satellites, and the evaluation of the model's representation of spatial and temporal variations in the optical depth. The inclusion of SOA in the Oslo CTM2 completes the set of major aerosol components in the model.

Several modelling studies have given estimates of the global burden and distribution of SOA from predominantly natural precursors (Chung and Seinfeld, 2002; Griffin et al., 1999a; Derwent et al., 2003; Henze and Seinfeld, 2006).

Some classes of compounds included in anthropogenic emissions are capable of forming SOA upon oxidation in the atmosphere. These include toluene, xylene and trimethylbenzenes. The contribution of these species to global SOA budgets has been evaluated by Tsigaridis and Kanakidou (2003) as well as Lack et al. (2004), and found to be a minor fraction (approximately 2-6\%, and 5-8\% respectively) of the contribution from naturally emitted precursors. Tsigaridis et al. (2005) evaluated the natural variability of the chemical production of SOA over a decade and found this to be equal to the formation of SOA from oxidation of anthropogenic VOC (8\%). Kanakidou et al. (2000) evaluated the anthropogenic effect on the concentrations of oxidants in the troposphere, and found that increases in tropospheric oxidants have lead to a factor of three to four increase in SOA production via $\mathrm{O}_{3}$ oxidation of biogenic precursor gases, between pre-industrial times and the present. They also found that an increase in anthropogenic POA has lead to greater SOA production.

In previous modelling studies it has been suggested that SOA formation as a result of hydrocarbon oxidation by $\mathrm{NO}_{3}$ is very minor in comparison to that by ozone and the hydroxyl radical (Chung and Seinfeld, 2002; Tsigaridis and Kanakidou, 2003), however the results of several measurement campaigns show oxidation of VOC by the nitrate radical may be significant (Brown et al., 2005; Vrekoussis et al., 2004; Geyer et al., 2003; Allan et al., 2002; Penkett et al., 1993). Chamber experiments also show that the oxidation of several monoterpene species by $\mathrm{NO}_{3}$ can lead to SOA formation (Griffin et al., 1999b; Bonn and Moorgat, 2002; Spittler et al., 2006).
As the Oslo CTM2 has not been used for detailed studies of SOA previously, the chemical scheme has been updated to account for the necessary processes. The SOA scheme used in this study is based upon that of Chung and Seinfeld (2002), however, it has been extended to include several new species. Additionally, the fields of $\mathrm{O}_{3}, \mathrm{OH}$ and $\mathrm{NO}_{3}$ used to oxidise the SOA precursors are calculated using an on-line chemistry scheme. The results presented here provide a new estimate of the global SOA production and burden and are an important contribution towards exploring the uncertainty in the global SOA production and burden figures. As the SOA scheme used here is similar to that of Chung and Seinfeld (2002), the results illustrate the sensitivity of SOA formation to the characteristics of the underlying CTM.

In the next section, a very brief description of the Oslo CTM2 will be provided, and the newly implemented SOA code will be described in some detail. The model experiments and results will be described in Sect. 3, and the contribution of $\mathrm{NO}_{3}$ oxidation to global and regional SOA formation will be discussed in Sect. 4. A summary and conclusions will be presented in Sect. 5 .

\section{Model description}

\subsection{The Oslo CTM2}

The Oslo CTM2 is a three dimensional off-line chemistry transport model, which was run with T42 (approximately $2.8^{\circ} \times 2.8^{\circ}$ ) horizontal resolution for this study. The model includes 40 layers between the surface and $10 \mathrm{hPa}$. The meteorological data used was generated by running the Integrated Forecast System (IFS) of the European Centre for Medium Range Weather Forecasts (ECMWF), for the year 2004, and was updated (off-line) in the CTM every three hours. The chemical time step in the troposphere is $15 \mathrm{~min}$, in the free troposphere the transport time step is one hour, in the boundary layer it is $15 \mathrm{~min}$. In the configuration used in this study, the model includes 122 gas and condensed phase chemical species, all of which are transported. The chemistry scheme accounts for the most important parts of the ozone- $\mathrm{NO}_{x}$ hydrocarbon chemistry cycle. For the chemistry calculations, the QSSA chemistry solver (Hesstvedt et al., 1978) is used.

Emissions of $\mathrm{CO} \quad\left(1121.8 \mathrm{Tg}(\mathrm{CO}) \mathrm{yr}^{-1}\right), \quad \mathrm{NO}_{\mathrm{x}}$ (44.3 $\mathrm{Tg}(\mathrm{N}) \mathrm{yr}^{-1}$ ) and non-methane hydrocarbons are taken from the Precursors of Ozone and their Effects in the Troposphere (POET) inventory (Granier et al., 2005).

More detailed descriptions of the model, as well as validation against measurements can be found in Berntsen and Isaksen (1997); Brunner et al. (2003); Berglen et al. (2004); Isaksen et al. (2005); Schulz et al. (2006) and Myhre et al. (2007). 
Table 1. The class to which the different precursors are assigned, and the fraction of the biogenic emissions they account for.

\begin{tabular}{lrc}
\hline Monoterpenes & $\begin{array}{c}\text { Contribution (\%) } \\
\text { and class }\end{array}$ \\
\hline$\alpha$-Pinene & 35 & I \\
$\beta$-Pinene & 23 & I \\
Limonene & 23 & II \\
Myrcene & 5 & IV \\
Sabinene & 5 & I \\
$\Delta^{3}$-Carene & 4 & I \\
Ocimene & 2 & IV \\
Terpinolene & 2 & III \\
$\alpha-\& \gamma-T e r p i n e n e$ & 1 & III \\
\hline ORVOC & & \\
Terpinoid Alcohols & 9 & IV \\
Sesquiterpenes & 5 & V \\
Terpenoid Ketones & 4 & I \\
\hline
\end{tabular}

\subsection{Biogenic VOC emissions}

Emissions of monoterpenes and Other Reactive Volatile Organic Compounds (ORVOC) are listed in Table 2 and are from the Global Emissions Inventory Activity (GEIA) data base. They are representative of 1990 (Guenther et al., 1995). The uncertainties associated with these emissions are estimated as being between a factor of 3 (Guenther et al., 1995) and a factor of 5 (Kanakidou et al., 2005). The emitted species are assigned to 12 tracers using global contribution factors from Griffin et al. (1999a) (see Table 1). The use of a single factor, globally, for the contribution of a particular species to the regional monoterpene or ORVOC emissions is justifiable as the contribution factors do not vary greatly with location (Kanakidou et al., 2005).

The 12 tracers are subsequently grouped into 5 classes, combining species which form oxidation products with similar aerosol forming properties (Chung and Seinfeld, 2002).

Emissions of isoprene are from the POET inventory (Granier et al., 2005), however they are scaled down to $220 \mathrm{Tg} \mathrm{yr}^{-1}$ (IPCC, 2001). This is rather low compared to the range of likely global isoprene emissions (250$750 \mathrm{Tg} \mathrm{yr}^{-1}$ ) given in Kanakidou et al. (2005), as well as other recent estimates (Lathière et al., 2006; Guenther et al., 2006), therefore the SOA contribution from the oxidation products of isoprene may be underestimated slightly. In the model, the total monthly emissions of monoterpenes and isoprene are distributed throughout the month, with emissions at a particular location and time depending on temperature and light. The emissions of monoterpenes have been modelled previously by an equation which does not take into account a light dependence (Guenther et al., 1995). Recently, a number of studies have shown that monoterpene emissions from
Table 2. Global, annual emissions of organic compounds used in the Oslo CTM2 for this study. For the conversion of the units of biofuel and fossil fuel POA from mass of carbon to mass of organic matter, emissions were multiplied by a factor of 1.6.

${ }^{1}$ Other Reactive Volatile Organic Compounds (ORVOC).

\begin{tabular}{lll}
\hline Species & Emission & Reference \\
\hline Toluene & $7.1 \mathrm{Tg} \mathrm{yr}^{-1}$ & Schultz et al. (2005) \\
M-xylene & $5.5 \mathrm{Tg} \mathrm{yr}^{-1}$ & Schultz et al. (2005) \\
Trimethylbenzene & $1.1 \mathrm{Tg} \mathrm{yr}^{-1}$ & Schultz et al. (2005) \\
Other aromatics & $3.4 \mathrm{Tg} \mathrm{yr}^{-1}$ & Schultz et al. (2005) \\
Monoterpenes $^{1}$ \\
ORVOC $^{1}$ & $127 \mathrm{Tg}(\mathrm{C}) \mathrm{yr}^{-1}$ & Guenther et al. (1995) \\
Isoprene & $259 \mathrm{Tg}(\mathrm{C}) \mathrm{yr}^{-1}$ & Guenther et al. (1995) \\
& $220 \mathrm{Tg} \mathrm{yr}^{-1}$ & Granier et al. (2005), \\
POA (bio/fossil fuel) & $8.8 \mathrm{Tg}(\mathrm{C}) \mathrm{yr}^{-1}$ & IPCC (2001) \\
POA (biomass burning) & $21.5 \mathrm{Tg} \mathrm{yr}^{-1}$ & van der Werf et al. (2004) \\
\hline
\end{tabular}

${ }^{1}$ Schultz, M. G., Pulles, T., Brand, R., van het Bolscher, M., and Dalsøren, S. B.: A global data set of anthropogenic CO, NOx, and NMVOC emissions for 1960-2000, in preparation, 2005.

many species do in fact exhibit a strong dependence on light, with negligible emissions taking place during the hours of darkness (Kesselmeier and Staudt, 1999; Kuhn et al., 2002; Otter et al., 2003; Greenberg et al., 2003; S.Moukhtar et al., 2005; Dindorf et al., 2006). Further, it has been shown during studies in the Amazon (Kuhn et al., 2002), in southern Africa (Greenberg et al., 2003) and in Europe (Dindorf et al., 2006), that the emissions of monoterpenes from many species may be modelled in the same way as isoprene emissions.

Here we apply the equation given by Guenther et al. (1995) to represent the temperature dependence of isoprene emissions, to scale both isoprene and monoterpene emissions, Eq. (1). Although this will not be correct for all species of plants, we believe that the majority of global emissions will be accurately represented in this way, and this represents a first step towards a better temporal integration of biogenic VOC emissions from inventories in the Oslo CTM2.

$$
C_{T}=\frac{\exp \left[\frac{C_{T 1}\left(T-T_{S}\right)}{R T_{S} T}\right]}{1+\exp \left[\frac{C_{T 2}\left(T-T_{M}\right)}{R T_{S} T}\right]}
$$

The temperature dependence of the emissions is given by $C_{T}$, and $R$ is the gas constant $\left(8.314 \mathrm{~J} \mathrm{~K}^{-1} \mathrm{~mol}^{-1}\right)$. The remaining variables are empirical coefficients $\left(C_{T 1}=95000 \mathrm{~J} \mathrm{~mol}^{-1}, \quad C_{T 2}=230000 \mathrm{~J} \mathrm{~mol}^{-1} \quad\right.$ and $T_{M}=314 \mathrm{~K}$ ) (Guenther et al., 1995). In order to limit the monoterpene and isoprene emissions to the day time, the solar elevation angle was calculated according to Holtslag and Ulden (1983) for all model grid points at the Earth's surface, with a time resolution of one hour, and emissions were switched off when the sun was below the horizon. When the sun was above the horizon, emissions were scaled 
Table 3. Reaction rates, taken from Chung and Seinfeld (2002). The temperature dependence of the rate constants is given by $\frac{k\left(T_{2}\right)}{k\left(T_{1}\right)}=\exp \left[-\frac{E}{R}\left(\frac{1}{T_{2}}-\frac{1}{T_{1}}\right)\right]$, where $T_{1}$ and $T_{2}$ are temperatures in $\mathrm{K}, E$ is the activation energy and $R$ is the gas constant. The value of $E / R$ for $\alpha$-pinene oxidation is used for all classes, i.e. $732 \mathrm{~K}$, $-400 \mathrm{~K},-490 \mathrm{~K}$ for reaction with $\mathrm{O}_{3}, \mathrm{OH}$ and $\mathrm{NO}_{3}$, respectively.

\begin{tabular}{lccc}
\hline Hydrocarbon & $k_{\mathrm{O}_{3}} \times 10^{18}$ & $k_{\mathrm{OH}} \times 10^{12}$ & $k_{\mathrm{NO}_{3}} \times 10^{12}$ \\
\hline Class I & 56 & 84 & 7 \\
Class II & 200 & 171 & 12 \\
Class III & 7700 & 255 & 89 \\
Class IV & 423 & 199 & 15 \\
Class V & 11,650 & 245 & 27 \\
\hline
\end{tabular}

using Eq. (1). During the day time, the emissions were dependent on temperature, and for simplicity, we did not include a light dependence. This is justifiable, considering the model grid resolution and the $1 \mathrm{~h}$ time steps used for emissions, as well as the overall uncertainty in the emissions and their distribution. During the polar night, no emission scaling was carried out, so that any (very small) emissions in these areas contained in the data files would be included. The total monthly isoprene or monoterpene emissions at a particular grid point are unchanged by this temperature and light scaling.

\subsection{Anthropogenic VOC emissions}

Emissions of toluene, m-xylene, trimethylbenzene, as well as the lumped species "other aromatic species", are from the emissions inventories produced in the RETRO (REanalysis of the TROpospheric chemical composition over the past 40 years) project (Schultz et al., 2005 ${ }^{1}$ ), for the year 2000. The total global emissions from these species are listed in Table 2. The seasonal dependence of the sources is taken into account in the RETRO inventory. In the Oslo CTM2, emissions of trimethylbenzene are added to the m-xylene tracer, as these species have similar aerosol forming properties (Odum et al., 1997). Emissions of "other aromatic species" are added to the toluene tracer. This latter lumping is necessary to reduce the number of species which the model needs to transport and react. Considering the lack of species-specific data for emissions, oxidation and partitioning, as well as the low total mass represented by the "other aromatic species" category, this lumping is justifiable, and will not greatly affect the results.

\footnotetext{
${ }^{1}$ Schultz, M. G., Pulles, T., Brand, R., van het Bolscher, M., and Dalsøren, S. B.: A global data set of anthropogenic CO, NOx, and NMVOC emissions for 1960-2000, in preparation, 2005.
}

Table 4. Reaction rates used for aromatics (Atkinson, 1994) and isoprene (Atkinson, 1990). The temperature dependence of the reaction rates is given by $k=A * \exp (B / T)$, where $T$ is the temperature in $\mathrm{K}$. Isoprene reaction with $\mathrm{OH}$ was considered to be the major pathway leading to SOA formation (Henze and Seinfeld, 2006), and in this model, reaction products from reaction with $\mathrm{O}_{3}$ or $\mathrm{NO}_{3}$ do not contribute to SOA. Reactions without a temperature dependence are indicated by N/A. The reaction rates for $\mathrm{m}$-xylene are the average of those for the ortho-, meta- and para- isomers. For reaction with $\mathrm{O} 3$, this is ${ }^{a}:\left(2.4 \times 10^{-13} \exp (-5586 / T)+5.37 \times\right.$ $\left.10^{-13} \exp (-6039 / T)+1.91 \times 10^{-13} \exp (-5586 / T)\right) / 3$.

\begin{tabular}{lcccc}
\hline & & $\mathrm{O}_{3}$ & & OH \\
& $A$ & $B$ & $A$ & $B$ \\
\hline Toluene & $2.34 \times 10^{-12}$ & -6694 & $5.96 \times 10^{-12}$ & N/A \\
M-Xylene & $a$ & $a$ & $1.72 \times 10^{-11}$ & N/A \\
Isoprene & - & - & $2.54 \times 10^{-11}$ & 410.0 \\
\hline
\end{tabular}

\subsection{Representation of POA}

POA can serve as a surface for the condensation of SOA (Kanakidou et al., 2005) and the mass of SOA in the model therefore depends partly upon the mass of POA. The treatment of POA in the Oslo CTM2 is similar to that described by Cooke et al. (1999). Emissions of OC from fossil fuel and biofuel combustion are from the inventory of Bond et al. (2004) and are representative of 1996. Total fossil fuel and biofuel combustion OC emissions are about $8.8 \mathrm{Tg}(\mathrm{C}) \mathrm{yr}^{-1}$, with approximately a factor of two uncertainty (Bond et al., 2004). A scaling factor of 1.6 was used to convert from units of mass of OC, for fossil fuel and biofuel combustion, to units of mass of organic matter (OM) (Turpin and Lim, 2001; Yttri et al., 2007). Emissions of OC from biomass burning (21.5 $\mathrm{Tg} \mathrm{yr}^{-1}$ in total) are taken from the Global Fire Emissions Database version 2 (GFEDv2), for 2004 (van der Werf et al., 2006). POA is transported in four variables, according to source (biomass or fossil fuel burning) and solubility. The hydrophobic part is assumed to be insoluble, while the hydrophilic part is completely soluble, and subject to wet removal by convective events and large scale rain. For the conversion of hydrophobic OC to hydrophilic OC, a conversion rate of $21 \%$ day $^{-1}$ is used (Maria et al., 2004). It should be noted that while POA is treated as non-volatile in this study, very recent research has indicated that this may not be strictly true. As emissions are diluted away from their sources, species with relatively high effective saturation concentrations may evaporate, in addition, organic species may undergo oxidation reactions leading to more volatile POA species (Shrivastava et al., 2006; Donahue et al., 2006; Robinson et al., 2007). 
Table 5. Mass based stoichiometric coefficients for the products formed by oxidation of the precursor hydrocarbons.

\begin{tabular}{lcccc}
\hline Hydrocarbon & \multicolumn{2}{c}{$\mathrm{OH}+\mathrm{O}_{3}$ oxidation } & & $\mathrm{NO}_{3}$ oxidation \\
\cline { 2 - 3 } & $\alpha_{i, 1,1}$ & $\alpha_{i, 1,2}$ & & $\alpha_{i, 2,1}$ \\
\hline Class I $^{\mathrm{a}}$ & 0.067 & 0.354 & & 1.0 \\
Class II $^{\mathrm{a}}$ & 0.239 & 0.363 & & 1.0 \\
Class III $^{\mathrm{a}}$ & 0.069 & 0.201 & & 1.0 \\
Class IV $^{\mathrm{a}}$ & 0.067 & 0.135 & & 1.0 \\
Class V$^{\mathrm{a}}$ & 1.0 & - & 1.0 \\
Toluene $^{\mathrm{b}}$ & 0.071 & 0.138 & - \\
M-Xylene $^{\mathrm{b}}$ & 0.038 & 0.167 & - \\
Isoprene $^{\mathrm{c}, \mathrm{d}}$ & 0.232 & 0.0288 & - \\
\hline
\end{tabular}

${ }^{a}$ From Chung and Seinfeld (2002).

${ }^{\mathrm{b}}$ From Tsigaridis and Kanakidou (2003).

${ }^{\mathrm{c}}$ From Henze and Seinfeld (2006).

$\mathrm{d}$ The only oxidant considered for isoprene is $\mathrm{OH}$.

\subsection{Formation of SOA}

Precursor hydrocarbons are transported in the model, and undergo gas phase oxidation via reaction with either $\mathrm{O}_{3}, \mathrm{OH}$ or $\mathrm{NO}_{3}$. The rate constants for the oxidation of monoterpenes and ORVOC are shown in Table 3, oxidation rates for the mxylene and toluene tracers as well as isoprene are shown in Table 4 . The use of the same $E / R$ values for the calculation of reaction rates in all classes may introduce some uncertainty, as the temperature dependence of the reaction rates will vary for different species, however this approach simplifies the chemistry scheme in the model and allows us to compare our results better with those of Chung and Seinfeld (2002).

A two product model (see Hoffmann et al., 1997) is used to represent the oxidation products of the precursor hydrocarbons and their aerosol forming properties, whereby the mass based stoichiometric coefficients $(\alpha)$ and equilibrium gas-particle partitioning coefficients $(K)$ are empirical values determined from chamber studies (Hoffmann et al., 1997). The values of the stoichiometric coefficients for product $k$ of the reaction of hydrocarbon $i$ and oxidant $j, \alpha_{i, j, k}$ are given in Table 5. The reaction products of oxidation via $\mathrm{OH}$ and $\mathrm{O}_{3}$ are considered together, and as the $\mathrm{NO}_{3}$ oxidation rate of $\beta$-pinene is used to represent $\mathrm{NO}_{3}$ oxidation of all class $\mathrm{I}-$ class $\mathrm{V}$ hydrocarbons, only one product is necessary in this case (Chung and Seinfeld, 2002; Griffin et al., 1999b).

The partitioning between the gas and aerosol phases is calculated assuming equilibrium and using the partitioning coefficients $K_{i, j, k}$, listed in Table 6. Under the assumption that the activity coefficient of each compound is constant, in the organic aerosol phase, the temperature dependence of the
Table 6. Gas to aerosol phase partitioning coefficients at $298 \mathrm{~K}$, except isoprene which is given for $295 \mathrm{~K}$.

\begin{tabular}{lcccc}
\hline Hydrocarbon & \multicolumn{2}{c}{$\mathrm{OH}+\mathrm{O}_{3}$ oxidation } & & $\mathrm{NO}_{3}$ oxidation \\
\cline { 2 - 3 } \cline { 5 - 5 } & $K_{i, 1,1}$ & $K_{i, 1,2}$ & & $K_{i, 2,1}$ \\
\hline class I $^{\mathrm{a}}$ & 0.184 & 0.0043 & & 0.0163 \\
class II $^{\mathrm{a}}$ & 0.055 & 0.0053 & & 0.0163 \\
class III $^{\mathrm{a}}$ & 0.133 & 0.0035 & & 0.0163 \\
class IV $^{\mathrm{a}}$ & 0.224 & 0.0082 & & 0.0163 \\
class V$^{\mathrm{a}}$ & 0.0459 & - & 0.0163 \\
Toluene $^{\mathrm{b}}$ & 0.053 & 0.0019 & - \\
M-Xylene $^{\mathrm{b}}$ & 0.042 & 0.0014 & - \\
Isoprene $^{\mathrm{c}, \mathrm{d}}$ & 0.00862 & 1.62 & - \\
\hline
\end{tabular}

${ }^{a}$ From Chung and Seinfeld (2002).

b From Tsigaridis and Kanakidou (2003).

${ }^{c}$ From Henze and Seinfeld (2006).

$\mathrm{d}$ The only oxidant considered for isoprene is $\mathrm{OH}$.

partitioning coefficients is given by:

$\frac{K_{i, j, k}(T)}{K_{i, j, k}\left(T_{r}\right)}=\frac{T}{T_{r}} \exp \left[\frac{\Delta H_{i, j, k}}{R}\left(\frac{1}{T}-\frac{1}{T_{r}}\right)\right]$

where $T_{r}$ is a reference temperature, $T$ is the temperature of interest, $R$ is the gas constant and $\Delta H_{i, j, k}$ is the enthalpy of vaporisation. In this study, we use $\Delta H=42 \mathrm{~kJ} \mathrm{~mol}^{-1}$ for all SOA (Henze and Seinfeld, 2006; Chung and Seinfeld, 2002).

The concentration of each of the oxidation products in the gas phase is given by:

$[G]_{i, j, k}=\frac{[A]_{i, j, k}}{K_{i, j, k} M_{o}}$

where $[G]_{i, j, k}$ is the gas phase product concentration, $[A]_{i, j, k}$ is the condensed phase product concentration and $M_{O}$ is the total mass of organic aerosol (i.e. the sum of POA and SOA). Using Eq. (4), $M_{o}$ is calculated iteratively,

$\sum_{i, j, k}\left[\frac{K_{i, j, k}(T)\left([A]_{i, j, k}^{0}+[G]_{i, j, k}^{0}\right)}{\left(1+K_{i, j, k}(T) M_{o}\right)}\right]+\frac{[P O A]}{M_{o}}=1$

from the initial gas and aerosol phase concentrations $\left([A]_{i, j, k}^{0}\right.$ and $[G]_{i, j, k}^{0}$ respectively). As the precursors are oxidised in the chemistry routine, which is called before the partitioning is calculated, newly oxidised gas phase products are included with the existing gas phase compounds in $[G]^{0}$. The final aerosol phase concentration is calculated using:

$[A]_{i, j, k}=\frac{K_{i, j, k} M_{o}\left([A]_{i, j, k}^{0}+[G]_{i, j, k}^{0}\right)}{\left(1+K_{i, j, k} M_{o}\right)}$

and the final gas phase concentration can be calculated using Eq. (3). The partitioning calculation is performed after every gas phase chemistry integration, in this study every $900 \mathrm{~s}$. 
Table 7. The Henry's Law coefficients used for:

${ }^{\mathrm{a}}$ The biogenic parent hydrocarbons and the biogenic oxidation products (including isoprene), (Chung and Seinfeld, 2002);

${ }^{\mathrm{b}}$ All of the aromatic oxidation products (except product 1 of $\mathrm{m}$-xylene oxidation, which is given separately), (Tsigaridis and Kanakidou, 2003).

${ }^{\mathrm{c}}$ From (Tsigaridis and Kanakidou, 2003).

\begin{tabular}{lc}
\hline Class & $\mathrm{H}\left(\mathrm{M} \mathrm{atm}^{-1}\right.$ at $\left.298 \mathrm{~K}\right)$ \\
\hline I & $0.023^{\mathrm{a}}$ \\
II & $0.07^{\mathrm{a}}$ \\
III & $0.067^{\mathrm{a}}$ \\
IV & $54^{\mathrm{a}}$ \\
V & $0.049^{\mathrm{a}}$ \\
Bio. Prod. $^{\mathrm{a}}$ & $1 \times 10^{5}$ \\
Aromat.Prod. $^{\mathrm{b}}$ & $1 \times 10^{3}$ \\
Prod. 1 m-xylene $^{\mathrm{c}}$ & $1 \times 10^{4}$ \\
\hline
\end{tabular}

\subsection{SOA and Precursor Loss Processes}

A number of loss processes must be included, both for the gas and aerosol phase oxidation products, as well as for the precursor hydrocarbons. We assume that $80 \%$ of the aerosol phase oxidation products dissolve into cloud droplets when clouds are present and for all the gas phase oxidation products of SOA precursors, a Henry's Law coefficient of $H=1 \times 10^{5} \mathrm{M} \mathrm{atm}^{-1}$ is used (Chung and Seinfeld, 2002), with a temperature dependence given by Eq. (6),

$\frac{d \ln H}{d T}=\frac{\Delta H_{A}}{R T^{2}}$

where $\Delta H_{A} / R=-12 \mathrm{~K}$ (for all precursor hydrocarbons and oxidation products), and $\Delta H_{A}$ is the heat of dissolution. The temperature dependence of the Henry's Law coefficients for the precursor hydrocarbons does not need to be accounted for, and the values used for each class of hydrocarbons are given in Table 7.

Wet deposition related to large scale as well as convective systems is represented in the model, and depends on the amount of precipitation crossing grid box boundaries, which is a model input field. In the case of large scale rain, the cloud fraction and amount of mass exchanged advectively is used to put an upper limit on the amount of a tracer which can be removed from a grid box. An iterative approach is used to calculate condensed water available for taking up gas phase species in convective clouds. The wet deposition routines are described thoroughly in Berglen et al. (2004).

A dry deposition velocity of $0.1 \mathrm{~cm} \mathrm{~s}^{-1}$ is applied in the lowest model layer, for all SOA species (Liousse et al., 1996).

\section{Results}

In this study, two main model experiments were carried out, in the first (" $R_{1}$ "), SOA was allowed to partition into existing organic aerosol. In the second experiment (" $R_{\text {sulf }}$ "), SOA was allowed to condense into ammonium sulphate aerosol as well as existing organic aerosol.

Ammonium sulphate aerosol has been used in many smog chamber experiments as a seed aerosol (Odum et al., 1997; Kroll et al., 2007; Northcross and Jang, 2007; Kleindienst et al., 1999; Griffin et al., 1999b). It was found by Kleindienst et al. (1999) that even with relatively high concentrations of ammonium sulphate aerosol, the partitioning model of Odum et al. (1997) described the SOA yield satisfactorily. Therefore, it is possible that the dry mass of ammonium sulphate aerosol can not simply be added to the existing organic aerosol in order to calculate the SOA partitioning. Nevertheless, doing so provides a useful sensitivity experiment. A study by Edney et al. (2000) suggests that the amount of water in the ammonium sulphate aerosol does not affect yields of SOA formed from toluene oxidation products. In this study, liquid water in ammonium sulphate aerosols has been assumed not to affect the partitioning of any semi-volatile organic species.

As a sensitivity test, a third experiment $\left(R_{\max }\right)$ was run where the partitioning coefficients were increased to $1 \times 10^{15}$ so that essentially all of the semi-volatile species formed from the oxidation of SOA precursors partitioned to the aerosol phase. This test then provides the upper limit of the mass of SOA which can be formed in this model, with the current precursor emissions, and oxidation product yields.

\subsection{Global production and burden of SOA}

The total global production of SOA is a very uncertain quantity, as the results of previous modelling studies show. Using a similar approach to that used here, Chung and Seinfeld (2002) estimate a total annual SOA production of about 11.2 $\mathrm{Tg} \mathrm{yr}^{-1}$, while Tsigaridis and Kanakidou (2003) suggest that the SOA production from biogenic volatile organic compounds (VOC) might range from 2.5 to $44.5 \mathrm{Tg} \mathrm{yr}^{-1}$, with an additional contribution from anthropogenic VOC of 0.05 to $2.62 \mathrm{Tg} \mathrm{yr}^{-1}$. A range of about $12 \mathrm{Tg} \mathrm{yr}^{-1}$ to $70 \mathrm{Tg} \mathrm{yr}^{-1}$ of total SOA formation is given by Kanakidou et al. (2005), summarising the results of several different model studies. The total tropospheric SOA production for 2004 was calculated to be $55 \mathrm{Tg} \mathrm{yr}^{-1}$, for $R_{1}$, which is within the higher end of the range of these values. The SOA production for 2004 in $R_{\text {sulf was }} 69 \mathrm{Tg} \mathrm{yr}^{-1}$.

Setting the partitioning coefficients to $1 \times 10^{15}$ in $R_{\max }$ lead to an annual production of $178 \mathrm{Tg} \mathrm{yr}^{-1}$, and a global burden of $2.1 \mathrm{Tg}$.

The annual mean SOA burden for 2004, in $R_{1}$, was calculated as $0.52 \mathrm{Tg}$, which is again significantly larger than the $0.19 \mathrm{Tg}$ calculated by Chung and Seinfeld (2002), but closer 
Table 8. The annual production and burden for the different model runs.

\begin{tabular}{lccl}
\hline Run & $\begin{array}{c}\text { Production } \\
(\mathrm{Tg} / \mathrm{yr})\end{array}$ & $\begin{array}{c}\text { Burden } \\
\mathrm{Tg}\end{array}$ & Description \\
\hline$R_{1}$ & 55 & 0.52 & condensation on POA \\
$R_{\text {sulf }}$ & 69 & 0.7 & condensation on POA and ammonium sulphate \\
$R_{\max }$ & 178 & 2.1 & complete partitioning to aerosol \\
$R_{\text {age }}$ & 65 & 0.67 & 1.15 day aging time for hydrophobic POA \\
\hline
\end{tabular}

to the $0.39 \mathrm{Tg}$ calculated by Henze and Seinfeld (2006). Other global estimates of SOA burdens, with SOA schemes of varying complexity include $0.36 \mathrm{Tg}$ (Griffin et al., 1999a), 1.2-1.6 Tg (Kanakidou et al., 2000), 1.4 Tg (Derwent et al., 2003) and 0.05-0.39 Tg (Tsigaridis and Kanakidou, 2003). The SOA burden for $R_{\text {sulf }}$ was $0.70 \mathrm{Tg}$.

The production and the burden for the various model runs performed in this study are summarised in Table 8.

One of the reasons that $R_{1}$ results in a larger value for total SOA production than that of Chung and Seinfeld (2002), despite a similar treatment of SOA formation, is the inclusion of isoprene and anthropogenically emitted aromatics as SOA precursors. This leads to an additional formation of $15 \mathrm{Tg} \mathrm{yr}^{-1}$ of SOA from the isoprene oxidation products (which accounts for about $28 \%$ of the annual average global burden). The contribution from aromatics is $2.5 \mathrm{Tg} \mathrm{yr}^{-1}$. The additional aerosol mass also leads to an enhancement of the SOA formation from other hydrocarbons. SOA formation via isoprene oxidation was added to an existing SOA scheme similar to that of Chung and Seinfeld (2002), by Henze and Seinfeld (2006), who found that the global SOA produced directly from the oxidation products of isoprene was $6.2 \mathrm{Tg} \mathrm{yr}^{-1}$, or about $71 \%$ of the production due to other VOC in their model. They also noted that the extra aerosol enhanced the production of SOA from other VOC in their model by $17 \%$. However, isoprene emissions of around $500 \mathrm{Tg} \mathrm{yr}^{-1}$ are used in the model of Henze and Seinfeld (2006) (compared with the $220 \mathrm{Tg} \mathrm{yr}^{-1}$ used here), so this can not be the sole explanation for the greater SOA production calculated in the present study.

Other factors which may contribute to the higher SOA burden in our model, as compared to that of Chung and Seinfeld (2002) include the transport of aerosol components by the model and the concentrations (and transport) of oxidants $\left(\mathrm{O}_{3}\right.$, $\mathrm{OH}, \mathrm{NO}_{3}$ ) used. Also, an exponential decay lifetime of 1.15 days was used by Chung and Seinfeld (2002) to convert hydrophobic POA into hydrophilic POA, which is shorter than the $21 \%$ day $^{-1}$ used here, however, the sensitivity of SOA burden to the aging rate of the POA was tested by using the same 1.15 day aging time in our model, and performing a run which was otherwise identical to $R_{\text {sulf }}$ (run $R_{\text {age }}$ ), and the change in SOA burden was found to be small (the annual mean burden reduced to $0.67 \mathrm{Tg}$ ). The effect of the rate of POA aging was also investigated by Tsigaridis and Kanaki- dou (2003), who found a small change in the production of SOA $(-7 \%)$ when a constant aging rate was used, rather than a rate dependent on $\mathrm{O}_{3}$ concentrations and relative humidity.

With regard to transport, the GISS GCM II', which was used by Chung and Seinfeld (2002), has a more rapid transport of tracers from the source regions than the Oslo CTM2 (Schulz et al., 2006). This can reduce POA over areas with high levels of SOA precursors, reduce the concentrations of oxidation products and thus affect partitioning, or it could result in a faster transport of SOA into model levels with clouds, where wet removal is efficient. In addition, differences in cloud water fluxes and precipitation cause different removal rates for a species in two different models, even if the solubility of the species is the same in both models.

The contribution of each of the modelled SOA species to the total global SOA production is shown in Table 9. The oxidation products of the class I hydrocarbons make the largest contribution of any species to the global SOA production in both experiments (about $32 \%$ in both $R_{1}$ and $R_{\text {sulf }}$ ), mainly due to $\mathrm{NO}_{3}$ oxidation. The second largest contribution is from the oxidation products of isoprene (27\% and $25 \%$ in $R_{1}$ and $R_{\text {sulf }}$ respectively). Allowing the condensation of semivolatile species into ammonium sulphate aerosols not only increased the total SOA production, but it increased the importance of anthropogenic SOA precursors from about $4.5 \%$ in $R_{1}$ to $9.4 \%$ in $R_{\text {sulf }}$. The greater enhancement of anthropogenic SOA over natural SOA is a result of the co-location of the ammonium sulphate aerosol source and the sources of the anthropogenic SOA precursors. This effect is particularly evident in the eastern USA, Europe and South East Asia.

A similar study was carried out by Tsigaridis and Kanakidou (2003), where the effect of SOA adsorption into sulphuric and ammonium aerosols was investigated. They found that the total SOA production increased from $7.2 \mathrm{Tg} \mathrm{yr}^{-1}$ to $13.3 \mathrm{Tg} \mathrm{yr}^{-1}$, an increase of around $85 \%$, if reversible uptake is assumed, as it is here. This is substantially larger than the $25 \%$ increase between $R_{1}$ and $R_{\text {sulf }}$. Adsorption into sulphuric and ammonium aerosols caused the fraction of the total production due to anthropogenic SOA precursors to increase from about $3.8 \%$ to $5.3 \%$ (Tsigaridis and Kanakidou, 2003).

The surface concentration and total column amount of SOA for both model runs are shown in Fig. 1, as an annual mean. The regions with the highest SOA concentrations are 


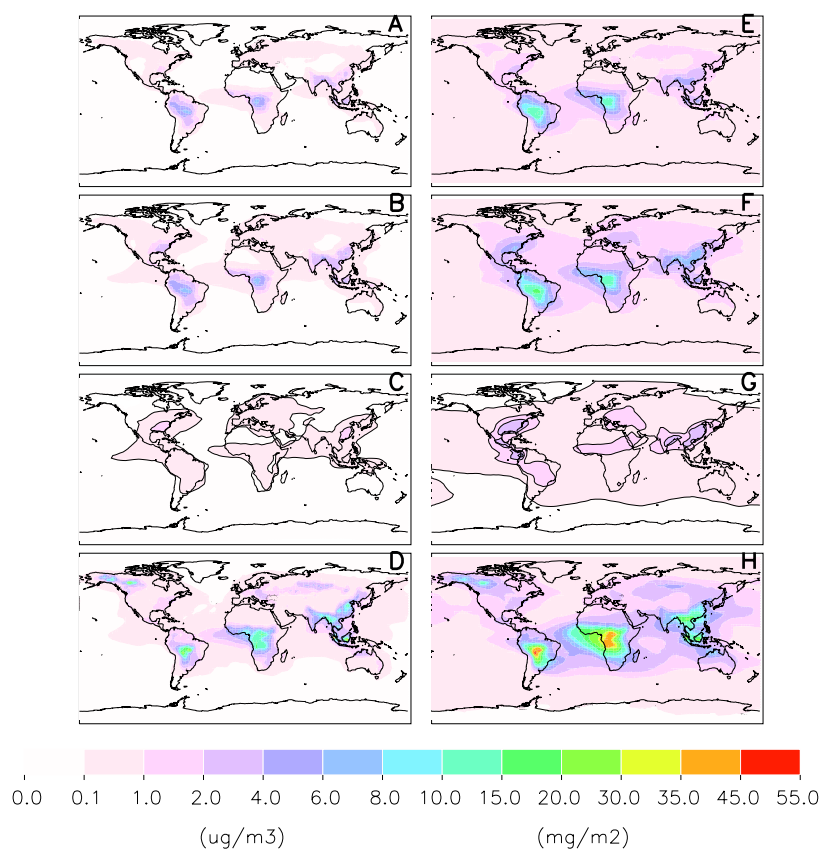

Fig. 1. Annual mean plots of SOA at the surface from runs $R_{1}$ and

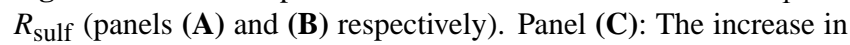
annual mean SOA concentration at the surface in $R_{\text {sulf }}$ (i.e. $R_{\text {sulf }}-$ $R_{1}$ ). Panel (D): Annual mean primary organic aerosol at the surface. Panels (E-H): as for (A-D), except values are for an integrated column.

those where emissions of precursors are highest, for example South America, and Africa. The supply of oxidants and POA has an impact on the SOA concentrations, which are also high in relatively polluted regions such as the east coast of North America, parts of Asia, and Europe, where the concentration of POA is highest (Panels D and H). Including the condensation of SOA to ammonium sulphate aerosol generally increases the SOA burden over industrialised areas, especially South East Asia and the east coast of North America, although a smaller increase is also visible over southern Europe (Panels $\mathrm{C}$ and $\mathrm{G}$ ). In $R_{\text {sulf }}$, SOA makes up the majority of the organic aerosol at the surface, on the east coast of North America, however this is not the case in other industrialised areas. For the column values, SOA is found to be the dominant contributor to total organic aerosol over part of Europe, as well as a significant part of North America. The major fraction of organic aerosol over Asia, however, remains POA.

\subsection{Vertical distribution of $\mathrm{OA}$}

The annual, zonal mean concentration of SOA and POA, from run $R_{1}$ are shown in Fig. 2, for altitudes between the surface and $40 \mathrm{hPa}$. Concentrations of POA are highest below about $700 \mathrm{hPa}$ in the tropics, consistent with a major

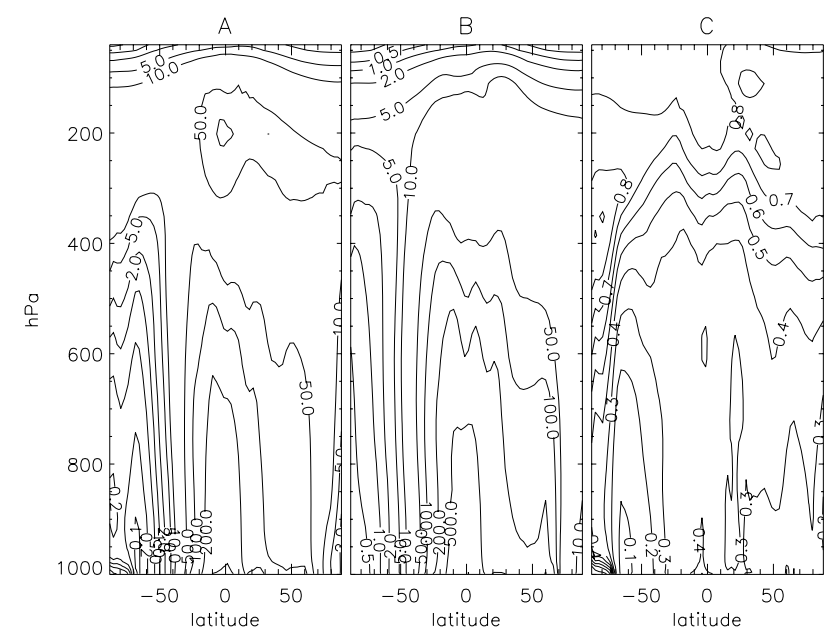

Fig. 2. Annual, zonal mean SOA (A), POA (B), from run $R_{1}$. Units are $n g$ (organic matter) $\mathrm{m}^{-3}$. The fraction of total OA made up of SOA is shown in panel $(\mathbf{C})$.

biomass burning source. Values are also high at northern mid latitudes, due to fossil fuel combustion. The distribution of the SOA shows similar patterns, as emissions of precursors are also high in the tropics, and concentrations of POA mass available for condensation are also high. Concentrations of SOA and POA generally decrease with increasing altitude, due to wet deposition. However, a secondary maximum for SOA is found in the upper troposphere, as decreasing temperatures force more of the semi-volatile oxidation products into the aerosol phase. This effect is also illustrated by panel C of Fig. 2, which shows how the SOA proportion of total OA increases with increasing altitude. The secondary SOA maximum in the upper troposphere has also been found in other model studies, for example Chung and Seinfeld (2002); Tsigaridis and Kanakidou (2003). Figure 2 is comparable with Figs. 7-9 of Chung and Seinfeld (2002). The POA shown in Fig. 7 of Chung and Seinfeld (2002) is greater than that in the present study, at all altitudes, due to the much larger fossil and bio-fuel OA emissions in the data set of Liousse et al. (1996) (approximately $80 \mathrm{Tg}$, compared to the $35 \mathrm{Tg}$ used here). Near the surface, global, annual mean, area weighted SOA concentrations in $R_{1}$ are higher than in Chung and Seinfeld (2002) (87.4 $\mathrm{ng} \mathrm{m}^{-3}$ compared to $77.53 \mathrm{ng} \mathrm{m}^{-3}$ at $959 \mathrm{hPa}$ ), which can be explained by the additional precursors used in this study, as well as an increased oxidation by $\mathrm{NO}_{3}$, which leads to a higher yield of condensible products. Although concentrations of SOA in $R_{1}$ are higher than in Chung and Seinfeld (2002) at low latitudes, they drop off faster towards the poles, especially in the Northern Hemisphere. Higher in the troposphere, the difference in the SOA loading increases, for example, at $201 \mathrm{hPa}$, we find mean SOA concentrations of $38.5 \mathrm{ng} \mathrm{m}^{-3}$, compared to the $19.5 \mathrm{ng} \mathrm{m}^{-3}$ given by Chung and Seinfeld (2002). This may 
be due to a more rapid transport of condensible species to the upper troposphere, as the Oslo CTM2 is known to have a relatively strong convective transport, or also partly due to differences in upper tropospheric temperature between the models.

3.3 SOA lifetimes and the contribution of different species to SOA production

The annual average lifetime of SOA was calculated to be 3.2 days in $R_{1}$, increasing to 3.7 days in $R_{\text {sulf. }}$. Both these values are significantly shorter than the 6.2 days given by Chung and Seinfeld (2002). As the major loss process for SOA in both studies was calculated to be wet deposition (here it was found to be, on average, 95\% of the total loss for 2004) and the same scavenging efficiency was used for SOA, the difference probably lies in the calculation of convection and precipitation in the models. The annual mean lifetimes of different species range between about 2.7 and 4.6 days (Table 9), with one of the oxidation products of isoprene having the longest lifetime in both model runs.

As allowing SOA to partition to ammonium sulphate aerosols changes the distribution of the SOA burden, the increase in SOA lifetime between $R_{1}$ and $R_{\text {sulf }}$ may be explained by an increase in the SOA burden in mid latitude (industrialised) areas where the wet deposition is not as active as in the tropics.

\subsection{Comparison with measurements}

In order to compare the mass of organic aerosol (OA) that the model predicts with measurements from a number of sites, mean burdens of organic aerosol have been calculated, from both model and measurement data. These values are shown in Table 10. Total OA mass concentration, as well as the concentration of SOA alone are shown for runs $R_{1}$ and $R_{\text {sulf }}$, additionally the total OA concentration when all semi-volatile species are partitioned to the aerosol phase is shown $\left(R_{\max }\right)$. All the sites except Ispra and Nanjing are rural or background sites, and the latter two sites are included here as they are located in large industrialised agglomerations, where the modelled aerosol levels should be elevated.

The measurement data in the first section of Table 10 comes from the Interagency Monitoring of Protected Visual Environments (IMPROVE) Aerosol Network data base, and is a mean of all values available at each selected station for 2004. The stations were selected based on their location, to provide data points spread over most of North America. The modelled values were interpolated to the latitude and longitude of the station and a mean was calculated over the same days as for the measurements, using data from the model level with an altitude closest to the altitude of the measurements. The modelled total organic aerosol values from $R_{1}$ are lower than the measured values, for all IMPROVE stations except Brigantine. However, all modelled values except
Table 9. The lifetimes and contribution to total SOA production of the modelled SOA species. Subscript indexes correspond to the $i$ 's and $j$ 's and $k$ 's in Table 5. The first set of numbers are from $R_{1}$, whereas those in brackets are from $R_{\text {sulf }}$.

\begin{tabular}{|c|c|c|c|c|}
\hline $\begin{array}{l}\text { Precursor } \\
\text { or class }\end{array}$ & oxidant & species & $\begin{array}{c}\text { lifetime } \\
\text { (hours) }\end{array}$ & $\begin{array}{c}\text { Contribution } \\
\text { to production (\%) }\end{array}$ \\
\hline \multicolumn{5}{|c|}{ Product 1} \\
\hline I & $\mathrm{OH} / \mathrm{O}_{3}$ & $\mathrm{SOA}_{111}$ & $95.4(101.2)$ & $6.2(6.0)$ \\
\hline II & $\mathrm{OH} / \mathrm{O}_{3}$ & $\mathrm{SOA}_{211}$ & $88.0(95.7)$ & $5.5(5.4)$ \\
\hline III & $\mathrm{OH} / \mathrm{O}_{3}$ & $\mathrm{SOA}_{311}$ & $92.6(97.3)$ & $0.29(0.3)$ \\
\hline IV & $\mathrm{OH} / \mathrm{O}_{3}$ & $\mathrm{SOA}_{411}$ & $90.0(94.2)$ & $2.5(2.3)$ \\
\hline $\mathrm{V}$ & $\mathrm{OH} / \mathrm{O}_{3}$ & $\mathrm{SOA}_{511}$ & $82.3(87.5)$ & $11.5(10.7)$ \\
\hline Isoprene & $\mathrm{OH}$ & $\mathrm{SOA}_{611}$ & $78.5(86.8)$ & $17.8(17.6)$ \\
\hline Xylene & $\mathrm{OH}$ & $\mathrm{SOA}_{711}$ & $65.8(77.9)$ & $0.36(0.3)$ \\
\hline Toluene & $\mathrm{OH} / \mathrm{O}_{3}$ & $\mathrm{SOA}_{811}$ & $72.4(90.8)$ & $1.3(1.5)$ \\
\hline \multicolumn{5}{|c|}{ Product 2} \\
\hline I & $\mathrm{OH} / \mathrm{O}_{3}$ & $\mathrm{SOA}_{112}$ & $74.2(81.1)$ & $8.8(8.7)$ \\
\hline II & $\mathrm{OH} / \mathrm{O}_{3}$ & $\mathrm{SOA}_{212}$ & $74.5(81.8)$ & $3.5(3.3)$ \\
\hline III & $\mathrm{OH} / \mathrm{O}_{3}$ & $\mathrm{SOA}_{312}$ & 73.7 (79.7) & $0.2(0.2)$ \\
\hline IV & $\mathrm{OH} / \mathrm{O}_{3}$ & $\mathrm{SOA}_{412}$ & 74.7 (81.9) & $1.7(1.6)$ \\
\hline Isoprene & $\mathrm{OH}$ & $\mathrm{SOA}_{612}$ & $109.7(112.0)$ & $8.9(7.7)$ \\
\hline Xylene & $\mathrm{OH}$ & $\mathrm{SOA}_{712}$ & $68.3(69.5)$ & $1.2(1.1)$ \\
\hline Toluene & $\mathrm{OH} / \mathrm{O}_{3}$ & $\mathrm{SOA}_{812}$ & $67.7(72.2)$ & $1.7(6.5)$ \\
\hline \multicolumn{5}{|c|}{ Product 1} \\
\hline I & $\mathrm{NO}_{3}$ & $\mathrm{SOA}_{121}$ & $72.7(88.1)$ & $16.7(17.1)$ \\
\hline II & $\mathrm{NO}_{3}$ & $\mathrm{SOA}_{221}$ & $72.3(88.4)$ & $3.3(3.2)$ \\
\hline III & $\mathrm{NO}_{3}$ & $\mathrm{SOA}_{321}$ & $73.2(89.5)$ & $0.3(0.3)$ \\
\hline IV & $\mathrm{NO}_{3}$ & $\mathrm{SOA}_{421}$ & $72.4(86.5)$ & $7.3(5.7)$ \\
\hline $\mathrm{V}$ & $\mathrm{NO}_{3}$ & $\mathrm{SOA}_{521}$ & $73.4(87.7)$ & $0.7(0.4)$ \\
\hline
\end{tabular}

those for Mammoth Cave NP and Chassahowitzka NWR are within a standard deviation of the mean measured value (although this is partly due to the large variability in the measurements, for example at Denali NP). Values from $R_{\text {sulf }}$ are generally closer to the measured values, yet there is still a significant underestimation of the measurements. In the model run where SOA partitioned entirely to the aerosol phase, most of the modelled values are close to the observed values, and in several cases, the modelled values are significantly higher than those observed.

The effect of irreversible condensation of SOA was considered by Tsigaridis and Kanakidou (2003), who found it lead to a $516 \%$ increase in SOA production. However, even if the condensation of SOA is considered to be irreversible, this will not lead to a partitioning of the entire semi-volatile mass into the aerosol phase, as described here (this is demonstrated by the increase in SOA production reported by Tsigaridis and Kanakidou (2003) when condensation onto sulphate and ammonia aerosols, as well as irreversible partitioning is considered).

For Europe, the model is compared with measurements made during a one year measurement campaign, which took place in 2002-2003 and focused on elemental and organic 
Table 10. A comparison between measured and modelled organic matter $(\mathrm{OM})$, for the three model experiments, $R_{1}, R_{\text {sulf }}$ and $R_{\text {max }}$. Also shown is the SOA component of the OM for these runs. With the exception of Ispra and Nanjing, these are rural or background sites. The latter two sites are located in large agglomerations spanning several model grid boxes. The IMPROVE measurements (first section of table) are from 2004, the years of the other measurements are given below. The modelled data corresponds to the year 2004, and for those measurements which do not cover the whole year, modelled averages have been calculated for the same time periods as the measurements.

1 EMEP measurements are annual means for one year from July 2002.

2 Puxbaum et al. (2000), May 1997

${ }^{3}$ Han et al. (2005), November 2001-August 2003

4 Takami et al. (1995), March-April 2003

5 Yang et al. (2005), November 2001

6 Virkkula et al. (2006), January 2000

\begin{tabular}{|c|c|c|c|c|c|c|c|c|c|}
\hline Station & $\begin{array}{c}\text { lat } \\
(\operatorname{degN})\end{array}$ & $\begin{array}{c}\text { lon } \\
(\operatorname{deg} \mathrm{E})\end{array}$ & $\begin{array}{l}\text { alt } \\
(\mathrm{m})\end{array}$ & $\begin{array}{c}\text { meas. OM } \\
\left(\mu \mathrm{g} \mathrm{m}^{-3}\right)\end{array}$ & $\begin{array}{l}\mathrm{OM}\left(R_{1}\right) \\
\left(\mu \mathrm{g} \mathrm{m}^{-3}\right)\end{array}$ & $\begin{array}{l}\operatorname{SOA}\left(R_{1}\right) \\
\left(\mu \mathrm{g} \mathrm{m}^{-3}\right)\end{array}$ & $\begin{array}{l}\mathrm{OM}\left(R_{\text {sulf }}\right) \\
\left(\mu \mathrm{g} \mathrm{m}^{-3}\right)\end{array}$ & $\begin{array}{l}\operatorname{SOA}\left(R_{\text {sulf }}\right) \\
\left(\mu \mathrm{g} \mathrm{m}^{-3}\right)\end{array}$ & $\begin{array}{c}\mathrm{OM}\left(R_{\max }\right) \\
\left(\mu \mathrm{g} \mathrm{m}^{-3}\right)\end{array}$ \\
\hline Brigantine NWR & 39.47 & -74.45 & 5 & $2.19 \pm 1.34$ & $3.18 \pm 2.29$ & $0.98 \pm 1.42$ & $3.70 \pm 2.77$ & $1.51 \pm 1.98$ & $7.10 \pm 6.60$ \\
\hline Chassahowitzka NWR & 28.75 & -82.55 & 4 & $2.65 \pm 1.49$ & $1.11 \pm 0.77$ & $0.48 \pm 0.60$ & $1.76 \pm 1.34$ & $1.12 \pm 1.22$ & $7.24 \pm 5.31$ \\
\hline Denali NP & 63.72 & -148.97 & 658 & $5.25 \pm 17.34$ & $1.06 \pm 2.35$ & $0.12 \pm 0.25$ & $1.06 \pm 2.33$ & $0.11 \pm 0.22$ & $1.28 \pm 2.54$ \\
\hline Hawaii Volcanoes NP & 19.43 & -155.26 & 1258 & $0.25 \pm 0.22$ & $0.06 \pm 0.04$ & $0.00 \pm 0.01$ & $0.08 \pm 0.07$ & $0.03 \pm 0.05$ & $0.24 \pm 0.32$ \\
\hline Mammoth Cave NP & 37.13 & -86.15 & 235 & $2.56 \pm 1.20$ & $1.05 \pm 0.76$ & $0.51 \pm 0.63$ & $2.09 \pm 1.83$ & $1.55 \pm 1.74$ & $7.14 \pm 7.09$ \\
\hline Mount Rainier NP & 46.76 & -122.12 & 439 & $1.79 \pm 1.57$ & $0.54 \pm 0.49$ & $0.11 \pm 0.17$ & $0.59 \pm 0.52$ & $0.16 \pm 0.23$ & $1.87 \pm 2.24$ \\
\hline Virgin Islands NP & 18.34 & -64.80 & 51 & $0.20 \pm 0.25$ & $0.11 \pm 0.07$ & $0.02 \pm 0.02$ & $0.17 \pm 0.11$ & $0.08 \pm 0.07$ & $0.80 \pm 0.61$ \\
\hline Weminuche Wilderness & 37.66 & -107.80 & 2750 & $0.80 \pm 0.69$ & $0.13 \pm 0.09$ & $0.04 \pm 0.05$ & $0.22 \pm 0.21$ & $0.14 \pm 0.18$ & $0.72 \pm 0.81$ \\
\hline Yellowstone NP 2 & 44.57 & -110.40 & 2425 & $0.98 \pm 0.88$ & $0.21 \pm 0.38$ & $0.07 \pm 0.15$ & $0.26 \pm 0.42$ & $0.12 \pm 0.20$ & $0.82 \pm 1.09$ \\
\hline Yosemite NP & 37.71 & -119.71 & 1603 & $2.91 \pm 6.73$ & $0.24 \pm 0.19$ & $0.05 \pm 0.07$ & $0.27 \pm 0.22$ & $0.09 \pm 0.08$ & $1.11 \pm 1.30$ \\
\hline Košetice & 49.35 & 15.05 & 534 & $6.41 \pm 3.65^{1}$ & $0.71 \pm 0.29$ & $0.11 \pm 0.11$ & $0.97 \pm 0.50$ & $0.37 \pm 0.37$ & $1.91 \pm 1.59$ \\
\hline Virolahti & 60.31 & 27.41 & 4 & $3.54 \pm 3.16^{1}$ & $1.60 \pm 1.60$ & $0.29 \pm 0.40$ & $1.87 \pm 1.71$ & $0.56 \pm 0.78$ & $3.49 \pm 3.57$ \\
\hline Langenbrügge & 52.48 & 10.45 & 74 & $7.31 \pm 5.80^{1}$ & $0.79 \pm 0.45$ & $0.13 \pm 0.15$ & $1.01 \pm 0.62$ & $0.36 \pm 0.38$ & $2.00 \pm 1.93$ \\
\hline Kollumerwaard & 53.20 & 6.17 & 1 & $4.40 \pm 3.25^{1}$ & $1.03 \pm 0.49$ & $0.13 \pm 0.18$ & $1.21 \pm 0.67$ & $0.32 \pm 0.40$ & $1.95 \pm 1.78$ \\
\hline Mace Head & 53.20 & -9.54 & 340 & $1.68 \pm 1.81^{1}$ & $0.13 \pm 0.10$ & $0.02 \pm 0.02$ & $0.20 \pm 0.15$ & $0.08 \pm 0.08$ & $0.35 \pm 0.34$ \\
\hline Ispra & 45.48 & 8.38 & 209 & $12.46 \pm 10.88^{1}$ & $0.63 \pm 0.24$ & $0.10 \pm 0.10$ & $0.86 \pm 0.41$ & $0.33 \pm 0.31$ & $1.86 \pm 1.65$ \\
\hline Birkenes & 58.23 & 8.15 & 190 & $2.67 \pm 2.62^{1}$ & $0.35 \pm 0.32$ & $0.06 \pm 0.11$ & $0.49 \pm 0.48$ & $0.20 \pm 0.29$ & $1.04 \pm 1.53$ \\
\hline Braganca & 41.49 & -6.46 & 691 & $7.38 \pm 8.39^{1}$ & $0.39 \pm 0.29$ & $0.06 \pm 0.05$ & $0.52 \pm 0.35$ & $0.19 \pm 0.14$ & $1.18 \pm 0.82$ \\
\hline Aspvreten & 58.48 & 17.23 & 20 & $3.39 \pm 2.72^{1}$ & $0.71 \pm 0.47$ & $0.12 \pm 0.16$ & $0.87 \pm 0.62$ & $0.28 \pm 0.36$ & $1.83 \pm 1.89$ \\
\hline Stará Lesná & 49.09 & 20.17 & 808 & $6.48 \pm 4.34^{1}$ & $0.80 \pm 0.35$ & $0.14 \pm 0.15$ & $1.12 \pm 0.65$ & $0.46 \pm 0.48$ & $1.95 \pm 1.70$ \\
\hline \multicolumn{10}{|l|}{ Nylsvley NR, } \\
\hline South Africa ${ }^{2}$ & 24.39 & 28.24 & 1000 & 22.56 & $0.21 \pm 0.04$ & $0.01 \pm 0.00$ & $0.27 \pm 0.06$ & $0.07 \pm 0.03$ & $0.82 \pm 0.12$ \\
\hline Gosan, Korea ${ }^{3}$ & 33.17 & 126.1 & & $3.44 \pm 2.96$ & $1.18 \pm 0.65$ & $0.12 \pm 0.18$ & $1.46 \pm 0.90$ & $0.40 \pm 0.56$ & $2.45 \pm 1.95$ \\
\hline Fukue Island, Japan ${ }^{4}$ & 32.8 & 128.7 & 27 & 5.03 & $1.35 \pm 0.79$ & $0.06 \pm 0.06$ & $1.45 \pm 0.87$ & $0.16 \pm 0.16$ & $1.86 \pm 1.17$ \\
\hline Nanjing, China ${ }^{5}$ & 32.04 & 118.49 & 267 & 22.79 & $3.30 \pm 1.65$ & $0.11 \pm 0.10$ & $3.43 \pm 1.77$ & $0.25 \pm 0.25$ & $3.77 \pm 2.00$ \\
\hline Aboa, Antarctica 6 & 73.03 & -13.05 & 470 & $0.12 \pm 0.07$ & $0.05 \pm 0.05$ & $0.00 \pm 0.00$ & $0.05 \pm 0.05$ & $0.0 \pm 0.0$ & $0.05 \pm 0.05$ \\
\hline
\end{tabular}

carbon, as part of the European Monitoring and Evaluation Programme (EMEP)(Yttri et al., 2007). The modelled data was averaged over the whole year and interpolated to the location of the measurement station. Again, values from $R_{1}$ significantly underestimate the measured values, by around $80 \%-95 \%$ in most cases. Some improvement is seen when the SOA is allowed to partition to the ammonium sulphate aerosol, however, the modelled values remain low. In contrast to what was seen in the comparison with the IMPROVE stations, the results of model run $R_{\max }$ are still significantly lower than most of the corresponding observations. The modelled OA at the Ispra site is only the sixth highest value for the set of European stations, whereas it is clearly the highest among the measured data, which suggests the model grid is too coarse to resolve this area of high emissions, or that this region is in reality poorly ventilated, and that this is not captured in the synoptic winds driving the model.

In the third section of Table 10, the modelled data is compared with measurements from stations in countries other than Europe and the USA. Where these measurements were made for less than a whole year, the modelled data is an average of the corresponding time period. The $R_{1}$ values are far lower than those measured, and again the $R_{\text {sulf }}$ values are generally higher than those in $R_{1}$ (except at Aboa). Also for these stations, partitioning all semi-volatile species to the aerosol phase does not produce enough OA to match the observed values. It is interesting to note the increase in modelled SOA between the background stations of Gosan and 


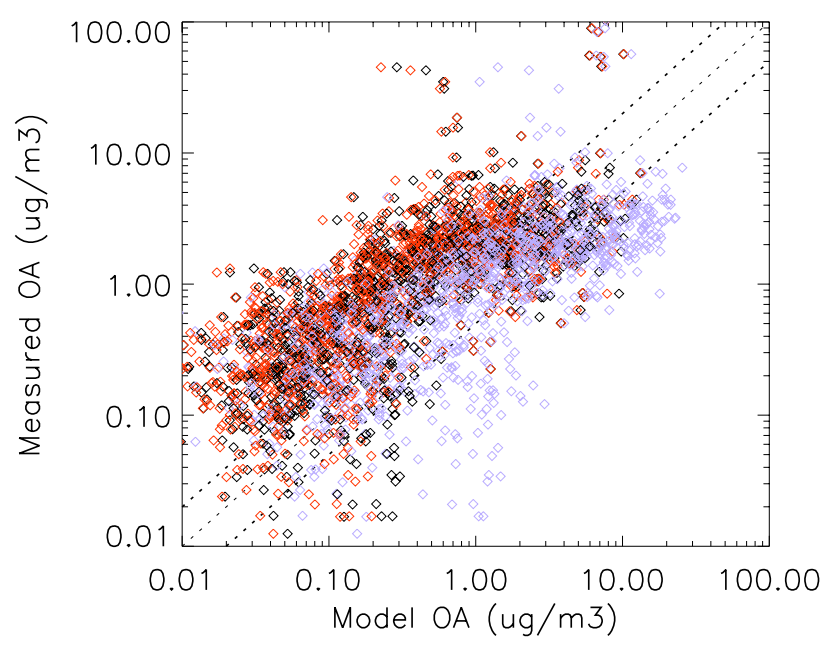

Fig. 3. Comparison of individual days of measurements from the IMPROVE sites in Table 10, with model data from the same days. The black symbols show data from $R_{1}, R_{\text {sulf }}$ is shown in red, and the purple symbols denote data from $R_{\max }$. The centre dashed line shows a ratio of $1: 1$, points within the upper and lower dashed lines are within a factor of two of the measured values.

Fukue, and the Nanjing station is less than a factor of two. This indicates that despite the fact that the measurement station is located in a region of elevated emissions larger than a model grid box, suburban SOA levels remain higher than the model can predict.

The fraction of OA which consists of SOA is rather variable and ranges from $0 \%$, at Aboa, to $74 \%$ at Mammoth

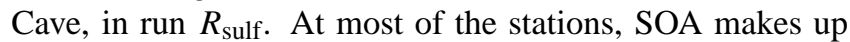
around $30 \%$ to $40 \%$ of the total modelled OA. Because of the greater existing aerosol mass in $R_{\text {sulf }}$, a higher fraction of OA consists of SOA than is the case in $R_{1}$, where SOA fractions range between about $10 \%$ and $30 \%$ at most stations.

In the last two sections of Table 10, some of the underestimation of the measured OC mass may be explained by the measurements being from a different year than the modelled values. As there are few reported OC measurements for 2004, in most regions it was necessary to use available measurements from other years to compare with the modelled data. Thus an additional uncertainty is introduced in the modelled values, firstly as meteorological conditions may vary between the measurement and modelled periods, bringing different levels of OC from source regions, and secondly as the biomass burning activity varies between years.

Model resolution may also explain a part of the general underestimation of the measured $\mathrm{OC}$ values. As the model grid boxes cover relatively large areas, it is not possible for the model to reproduce high OC values associated with either localised emissions, plumes, or topographical features in which aerosol tends to collect, such as large bowls and valleys.

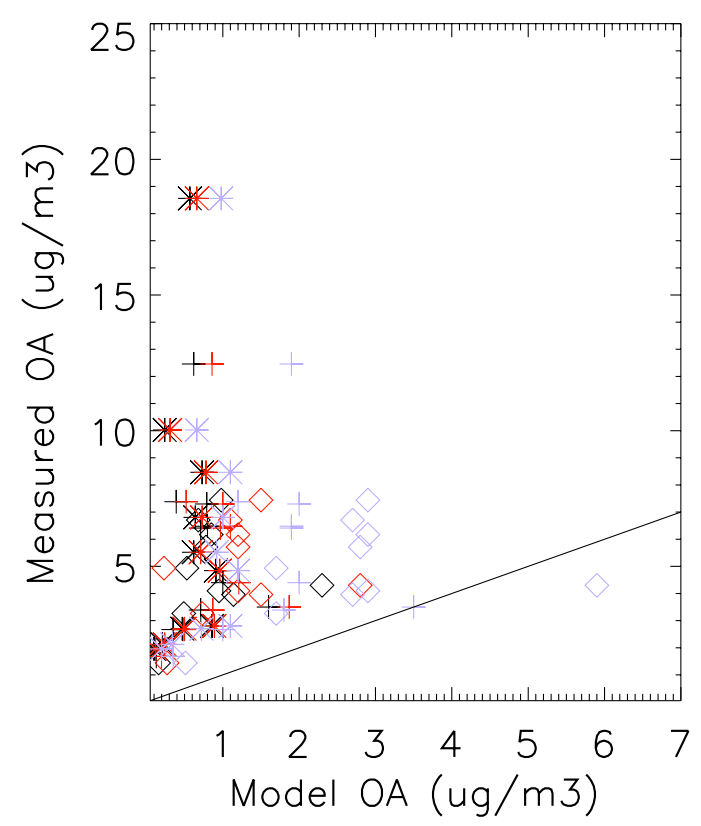

Fig. 4. Comparison of measurements from the EMEP sites in Table 10 , with model data. The black symbols show data from $R_{1}, R_{\text {sulf }}$ is shown in red, and the purple symbols denote data from $R_{\max }$. Annual mean data is represented by a plus sign, winter mean ( 1 October-1 April) data by an asterisk, and summer mean (1 April to 1 October) by a diamond. Note that the $\mathrm{x}$ - and $\mathrm{y}$-axis scales differ.

Although there are a few stations in Table 10 where the SOA values in $R_{\max }$ are significantly higher than the observed values, for most locations, even with all semi-volatile organic species partitioned to the aerosol phase (itself an unrealistic scenario), the model underestimates the observed levels of OA. This indicates that the cause of the underestimation does not lie with the partitioning of SOA between gas and aerosol phase, rather that emissions of precursors or POA may be too low (including the possibility of SOA precursors which are yet to be identified), or that loss processes in the model may be too fast.

The individual days of measurements which make up the means shown in Table 10 are plotted against modelled values for the same days in Fig. 3. Although the data in $R_{1}$ generally underestimates the measured values, there are also many days when the model matches or overestimates the measured values. The inclusion of condensation on sulphate aerosols makes little difference to the low bias in the modelled values, and the values from $R_{\max }$ give the best agreement, although they tend to slightly overestimate the measured values.

Data from the EMEP stations listed in Table 11 and Table 12 are shown in Fig. 4. Again, including condensation on sulphate aerosol leads to a slight improvement in the match between modelled and measured data, however as discussed above, even in $R_{\max }$, the model underestimates 
Table 11. Similar to Table 10, except for winter. IMPROVE winter values, and modelled values are for January, February and December 2004. EMEP winter means are for 1 October 2002-1 April 2003 (Yttri et al., 2007). Modelled values compared with the EMEP values are means for data from 1 January-1 April 2004 and 1 October-1 December 2004.

\begin{tabular}{|c|c|c|c|c|c|c|c|c|c|}
\hline Station & $\begin{array}{c}\text { lat } \\
(\operatorname{deg} \mathrm{N})\end{array}$ & $\begin{array}{c}\text { lon } \\
(\operatorname{deg} E)\end{array}$ & $\begin{array}{l}\text { alt } \\
(\mathrm{m})\end{array}$ & $\begin{array}{l}\text { meas. OM } \\
\left(\mu \mathrm{g} \mathrm{m}^{-3}\right)\end{array}$ & $\begin{array}{l}\mathrm{OM}\left(R_{1}\right) \\
\left(\mu \mathrm{g} \mathrm{m}^{-3}\right)\end{array}$ & $\begin{array}{l}\operatorname{SOA}\left(R_{1}\right) \\
\left(\mu \mathrm{g} \mathrm{m}^{-3}\right)\end{array}$ & $\begin{array}{l}\text { OM }\left(R_{\text {sulf }}\right) \\
\left(\mu \mathrm{g} \mathrm{m}^{-3}\right)\end{array}$ & $\begin{array}{c}\operatorname{SOA}\left(R_{\text {sulf }}\right) \\
\left(\mu \mathrm{g} \mathrm{m}^{-3}\right)\end{array}$ & $\begin{array}{c}\mathrm{OM}\left(R_{\max }\right) \\
\left(\mu \mathrm{g} \mathrm{m}^{-3}\right)\end{array}$ \\
\hline Brigantine NWR & 39.47 & -74.45 & 5 & $2.16 \pm 1.03$ & $1.48 \pm 0.57$ & $0.07 \pm 0.07$ & $1.53 \pm 0.59$ & $0.12 \pm 0.11$ & $1.81 \pm 0.85$ \\
\hline Chassahowitzka NWR & 28.75 & -82.55 & 4 & $3.02 \pm 2.17$ & $0.66 \pm 0.28$ & $0.11 \pm 0.09$ & $0.84 \pm 0.35$ & $0.30 \pm 0.17$ & $2.47 \pm 1.11$ \\
\hline Denali NP & 63.72 & -148.97 & 658 & $0.24 \pm 0.16$ & $0.02 \pm 0.01$ & $0.00 \pm 0.00$ & $0.02 \pm 0.01$ & $0.00 \pm 0.00$ & $0.04 \pm 0.03$ \\
\hline Hawaii Volcanoes NP & 19.43 & -155.26 & 1258 & $0.29 \pm 0.19$ & $0.04 \pm 0.02$ & $0.00 \pm 0.00$ & $0.06 \pm 0.02$ & $0.01 \pm 0.01$ & $0.14 \pm 0.06$ \\
\hline Mammoth Cave NP & 37.13 & -86.15 & 235 & $2.02 \pm 0.71$ & $0.46 \pm 0.17$ & $0.05 \pm 0.04$ & $0.58 \pm 0.24$ & $0.17 \pm 0.13$ & $0.96 \pm 0.51$ \\
\hline Mount Rainier NP & 46.76 & -122.12 & 439 & $0.84 \pm 0.91$ & $0.21 \pm 0.11$ & $0.01 \pm 0.01$ & $0.23 \pm 0.11$ & $0.02 \pm 0.01$ & $0.37 \pm 0.20$ \\
\hline Virgin Islands NP & 18.34 & -64.80 & 51 & $0.25 \pm 0.18$ & $0.06 \pm 0.06$ & $0.00 \pm 0.00$ & $0.07 \pm 0.06$ & $0.02 \pm 0.01$ & $0.26 \pm 0.15$ \\
\hline Weminuche Wilderness & 37.66 & -107.80 & 2750 & $0.50 \pm 0.24$ & $0.05 \pm 0.03$ & $0.01 \pm 0.00$ & $0.06 \pm 0.04$ & $0.02 \pm 0.02$ & $0.10 \pm 0.07$ \\
\hline Yellowstone NP 2 & 44.57 & -110.40 & 2425 & $0.44 \pm 0.20$ & $0.04 \pm 0.02$ & $0.00 \pm 0.00$ & $0.05 \pm 0.02$ & $0.01 \pm 0.01$ & $0.07 \pm 0.05$ \\
\hline Yosemite NP & 37.71 & -119.71 & 1603 & $0.41 \pm 0.29$ & $0.07 \pm 0.06$ & $0.00 \pm 0.01$ & $0.08 \pm 0.07$ & $0.01 \pm 0.01$ & $0.17 \pm 0.13$ \\
\hline Košetice & 49.35 & 15.05 & 534 & $6.80 \pm 4.15$ & $0.64 \pm 0.29$ & $0.05 \pm 0.05$ & $0.73 \pm 0.36$ & $0.14 \pm 0.15$ & $1.02 \pm 0.68$ \\
\hline Virolahti & 60.31 & 27.41 & 4 & $2.81 \pm 1.92$ & $0.85 \pm 0.50$ & $0.05 \pm 0.03$ & $0.89 \pm 0.51$ & $0.09 \pm 0.06$ & $1.06 \pm 0.52$ \\
\hline Langenbrügge & 52.48 & 10.45 & 74 & $8.47 \pm 6.83$ & $0.72 \pm 0.53$ & $0.06 \pm 0.07$ & $0.78 \pm 0.56$ & $0.12 \pm 0.12$ & $1.08 \pm 0.77$ \\
\hline Kollumerwaard & 53.20 & 6.17 & 1 & $4.85 \pm 3.49$ & $0.91 \pm 0.49$ & $0.05 \pm 0.05$ & $0.95 \pm 0.51$ & $0.09 \pm 0.09$ & $1.15 \pm 0.65$ \\
\hline Mace Head & 53.20 & -9.54 & 340 & $1.96 \pm 2.16$ & $0.10 \pm 0.12$ & $0.01 \pm 0.01$ & $0.12 \pm 0.15$ & $0.03 \pm 0.04$ & $0.19 \pm 0.25$ \\
\hline Ispra & 45.48 & 8.38 & 209 & $18.56 \pm 12.96$ & $0.57 \pm 0.28$ & $0.04 \pm 0.04$ & $0.66 \pm 0.32$ & $0.13 \pm 0.13$ & $0.98 \pm 0.58$ \\
\hline Birkenes & 58.23 & 8.15 & 190 & $2.12 \pm 2.48$ & $0.21 \pm 0.18$ & $0.01 \pm 0.02$ & $0.24 \pm 0.21$ & $0.04 \pm 0.05$ & $0.34 \pm 0.27$ \\
\hline Braganca & 41.49 & -6.46 & 691 & $10.02 \pm 11.02$ & $0.24 \pm 0.19$ & $0.02 \pm 0.02$ & $0.31 \pm 0.23$ & $0.09 \pm 0.08$ & $0.67 \pm 0.51$ \\
\hline Aspvreten & 58.48 & 17.23 & 20 & $2.70 \pm 2.13$ & $0.48 \pm 0.25$ & $0.04 \pm 0.04$ & $0.51 \pm 0.27$ & $0.07 \pm 0.06$ & $0.72 \pm 0.43$ \\
\hline Stará Lesná & 49.09 & 20.17 & 808 & $5.52 \pm 3.00$ & $0.62 \pm 0.30$ & $0.05 \pm 0.06$ & $0.71 \pm 0.39$ & $0.14 \pm 0.17$ & $0.92 \pm 0.66$ \\
\hline
\end{tabular}

Table 12. Similar to Table 10, except for Summer. IMPROVE summer values and modelled values are for June, July and August 2004, EMEP summer means are for 1 July 2002-1 October 2002 and 1 April 2003-1 July 2003 (Yttri et al., 2007). Modelled values compared with the EMEP values are means for 1 April 2004-1 October 2004.

\begin{tabular}{|c|c|c|c|c|c|c|c|c|c|}
\hline Station & $\begin{array}{c}\text { lat } \\
(\operatorname{degN})\end{array}$ & $\begin{array}{c}\text { lon } \\
(\operatorname{deg} \mathrm{E})\end{array}$ & $\begin{array}{l}\text { alt } \\
(\mathrm{m})\end{array}$ & $\begin{array}{l}\text { meas. OM } \\
\left(\mu \mathrm{g} \mathrm{m}^{-3}\right)\end{array}$ & $\begin{array}{l}\mathrm{OM}\left(R_{1}\right) \\
\left(\mu \mathrm{g} \mathrm{m}^{-3}\right)\end{array}$ & $\begin{array}{l}\operatorname{SOA}\left(R_{1}\right) \\
\left(\mu \mathrm{g} \mathrm{m}^{-3}\right)\end{array}$ & $\begin{array}{l}\mathrm{OM}\left(R_{\text {sulf }}\right) \\
\left(\mu \mathrm{g} \mathrm{m}^{-3}\right)\end{array}$ & $\begin{array}{c}\operatorname{SOA}\left(R_{\text {sulf }}\right) \\
\left(\mu \mathrm{g} \mathrm{m}^{-3}\right)\end{array}$ & $\begin{array}{c}\mathrm{OM}\left(\mathrm{R}_{\max }\right) \\
\left(\mu \mathrm{g} \mathrm{m}^{-3}\right)\end{array}$ \\
\hline Brigantine NWR & 39.47 & -74.45 & 5 & $2.71 \pm 1.61$ & $5.17 \pm 2.44$ & $2.49 \pm 1.63$ & $6.51 \pm 2.78$ & $3.84 \pm 2.05$ & $13.34 \pm 5.14$ \\
\hline Chassahowitzka NWR & 28.75 & -82.55 & 4 & $2.55 \pm 1.23$ & $1.61 \pm 1.00$ & $1.00 \pm 0.85$ & $2.95 \pm 1.74$ & $2.34 \pm 1.60$ & $11.55 \pm 4.56$ \\
\hline Denali NP & 63.72 & -148.97 & 658 & $17.99 \pm 30.26$ & $3.90 \pm 3.24$ & $0.44 \pm 0.31$ & $3.87 \pm 3.20$ & $0.41 \pm 0.27$ & $4.54 \pm 3.18$ \\
\hline Hawaii Volcanoes NP & 19.43 & -155.26 & 1258 & $0.19 \pm 0.23$ & $0.06 \pm 0.04$ & $0.01 \pm 0.02$ & $0.11 \pm 0.11$ & $0.06 \pm 0.09$ & $0.40 \pm 0.52$ \\
\hline Mammoth Cave NP & 37.13 & -86.15 & 235 & $3.25 \pm 1.42$ & $1.91 \pm 0.82$ & $1.27 \pm 0.68$ & $4.28 \pm 1.69$ & $3.64 \pm 1.63$ & $12.83 \pm 4.53$ \\
\hline Mount Rainier NP & 46.76 & -122.12 & 439 & $2.55 \pm 1.99$ & $0.85 \pm 0.55$ & $0.27 \pm 0.24$ & $0.97 \pm 0.61$ & $0.38 \pm 0.31$ & $3.96 \pm 2.70$ \\
\hline Virgin Islands NP & 18.34 & -64.80 & 51 & $0.16 \pm 0.32$ & $0.14 \pm 0.04$ & $0.03 \pm 0.01$ & $0.25 \pm 0.07$ & $0.14 \pm 0.04$ & $1.17 \pm 0.36$ \\
\hline Weminuche Wilderness & 37.66 & -107.80 & 2750 & $1.31 \pm 1.06$ & $0.22 \pm 0.09$ & $0.09 \pm 0.07$ & $0.43 \pm 0.26$ & $0.31 \pm 0.25$ & $1.59 \pm 0.80$ \\
\hline Yellowstone NP 2 & 44.57 & -110.40 & 2425 & $1.88 \pm 1.28$ & $0.49 \pm 0.69$ & $0.19 \pm 0.27$ & $0.60 \pm 0.73$ & $0.30 \pm 0.32$ & $2.08 \pm 1.35$ \\
\hline Yosemite NP & 37.71 & -119.71 & 1603 & $7.25 \pm 11.95$ & $0.41 \pm 0.17$ & $0.11 \pm 0.08$ & $0.48 \pm 0.23$ & $0.18 \pm 0.16$ & $2.49 \pm 1.28$ \\
\hline Košetice & 49.35 & 15.05 & 534 & $5.71 \pm 2.49$ & $0.78 \pm 0.43$ & $0.17 \pm 0.15$ & $1.21 \pm 0.68$ & $0.61 \pm 0.44$ & $2.78 \pm 1.76$ \\
\hline Virolahti & 60.31 & 27.41 & 4 & $4.30 \pm 3.96$ & $2.33 \pm 2.34$ & $0.53 \pm 0.59$ & $2.82 \pm 2.38$ & $1.03 \pm 1.05$ & $5.87 \pm 4.19$ \\
\hline Langenbrügge & 52.48 & 10.45 & 74 & $4.47 \pm 4.39$ & $0.85 \pm 0.57$ & $0.21 \pm 0.22$ & $1.24 \pm 0.81$ & $0.59 \pm 0.50$ & $2.91 \pm 2.15$ \\
\hline Kollumerwaard & 53.20 & 6.17 & 1 & $3.96 \pm 2.98$ & $1.15 \pm 0.69$ & $0.22 \pm 0.25$ & $1.48 \pm 0.93$ & $0.54 \pm 0.52$ & $2.75 \pm 2.08$ \\
\hline Mace Head & 53.20 & -9.54 & 340 & $1.44 \pm 1.34$ & $0.16 \pm 0.17$ & $0.03 \pm 0.03$ & $0.27 \pm 0.25$ & $0.14 \pm 0.12$ & $0.51 \pm 0.52$ \\
\hline Ispra & 45.48 & 8.38 & 209 & $6.70 \pm 2.30$ & $0.69 \pm 0.32$ & $0.16 \pm 0.13$ & $1.05 \pm 0.55$ & $0.53 \pm 0.39$ & $2.72 \pm 1.64$ \\
\hline Birkenes & 58.23 & 8.15 & 190 & $3.26 \pm 2.69$ & $0.49 \pm 0.45$ & $0.11 \pm 0.16$ & $0.73 \pm 0.66$ & $0.35 \pm 0.39$ & $1.74 \pm 1.93$ \\
\hline Braganca & 41.49 & -6.46 & 691 & $4.93 \pm 3.64$ & $0.53 \pm 0.34$ & $0.09 \pm 0.07$ & $0.73 \pm 0.39$ & $0.28 \pm 0.16$ & $1.70 \pm 0.88$ \\
\hline Aspvreten & 58.48 & 17.23 & 20 & $4.10 \pm 3.10$ & $0.95 \pm 0.74$ & $0.20 \pm 0.22$ & $1.24 \pm 0.89$ & $0.49 \pm 0.49$ & $2.93 \pm 2.10$ \\
\hline Stará Lesná & 49.09 & 20.17 & 808 & $7.44 \pm 5.24$ & $0.98 \pm 0.46$ & $0.23 \pm 0.19$ & $1.51 \pm 0.79$ & $0.77 \pm 0.57$ & $2.96 \pm 1.78$ \\
\hline
\end{tabular}


the measurements. Also included in Fig. 4 is a comparison of summer mean data (1 July-1 October 2002 and 1 April 2003-1 July 2003 for the measured data, and 1 April-1 October 2004 for the modelled data), indicated by the diamond symbols, and winter mean data (1 October 2002-1 April 2003 for the measured values, 1 October-31 December and 1 January-1 April 2004 for the modelled values), indicated by the asterisks. There is some indication that the model may represent the summer measurements better than winter or annual mean values, especially for data from $R_{\max }$.

Tables 11 and 12 show data for the same IMPROVE and EMEP stations as Table 10, for winter and summer respectively. The contribution of SOA to the total modelled OA is much lower in winter than in summer, due to the lower emissions of precursors. For $R_{1}$, SOA makes up less than $10 \%$ of the OA mass in winter at all stations. For the IMPROVE stations, $R_{1}$ winter time OA values are mostly around 10 $20 \%$ of the measured values. This fraction increases in summer, when the modelled values are significantly closer to the measured values for all the listed IMPROVE stations except Yosemite NP, where there is a huge increase in measured values in summer. In summer, the fraction of modelled OA which is SOA increases at all stations, to between about 30$60 \%$ for most stations, indicating that the reason for the increase in modelled OA in summer is predominantly due to the increase in SOA. Three of the IMPROVE stations (Chassahowitzka NWR, Hawaii Volcanoes NP and Virgin Islands NP) show lower measured OA values in summer than in winter, a feature that is not seen in the modelled values, which are all higher in summer than in winter. Similar patterns are seen for $R_{\text {sulf }}$, however the SOA fraction of modelled OA is higher than for $R_{1}$ in both summer and winter, being around $10-30 \%$ in winter and mostly over $50 \%$ in summer. The increase in modelled SOA in summer is greater for $R_{\text {sulf }}$ than in $R_{1}$. In $R_{\text {sulf }}$, the SOA fraction of OA at Denali NP is higher in winter than in summer.

For the EMEP stations, the SOA fraction of modelled OA is again very low in winter for $R_{1}$ (less than $10 \%$ ), but about $10-20 \%$ for most stations in $R_{\text {sulf }}$. Again the fractions increase in summer, to around $20 \%$ for $R_{1}$, and $40-50 \%$ for most stations in $R_{\text {sulf }}$. The modelled values for $R_{\text {sulf }}$ in summer compare much better with the measured values than in winter, with modelled values being within one standard deviation of the measurements for six stations. Although the modelled OA values were higher in summer than in winter for all EMEP stations, the measured OA values are lower in summer for six of the stations. The increase in modelled SOA between winter and summer for $R_{\text {sulf }}$ was higher than that seen in $R_{1}$.

At those stations where the measured summer OA values were higher than the winter values, the relative increase in OA from winter to summer was higher, in nearly all cases, for modelled values than for the measured values. This lead to the better agreement between modelled and measured values in summer. However, the absolute increase in modelled OA

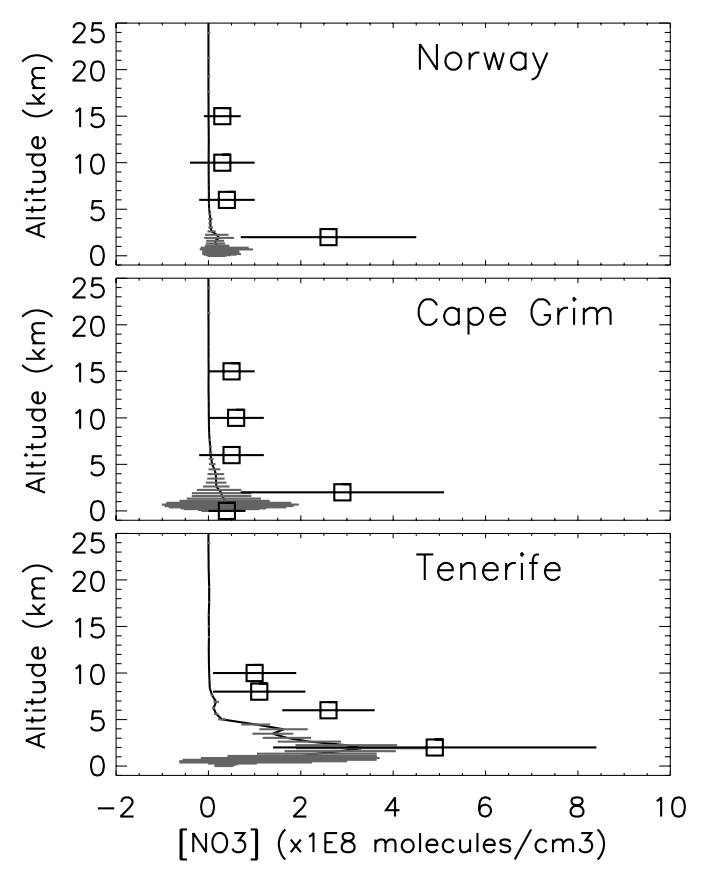

Fig. 5. Comparison of mean modelled $\mathrm{NO}_{3}$ (solid line, with range of one standard deviation shown by horizontal grey bars) and measurements at three locations (squares, with range of one standard deviation shown by horizontal bars, from Allan et al. 2002).

is mostly less than the measured increase, both for $R_{1}$ and $R_{\text {sulf. }}$. The increase in OA mass between summer and winter for $R_{\max }$ is larger than the measured increase for the majority of EMEP and IMPROVE stations.

This indicates that the underestimation of modelled OA may be due to both too low POA values (as these are dominant in winter), and a too small increase in SOA in summer. If the amount of POA was increased, and more SOA partitioned to the aerosol phase in summer, the comparison with measured OA values would be improved.

\section{Influence of $\mathrm{NO}_{3}$ on $\mathrm{SOA}$ formation}

As mentioned above, in this study, the oxidation of SOA precursors by $\mathrm{NO}_{3}$ is found to lead to a large fraction of the total SOA formation. This is examined in more detail here, and the influence of the yield of $\mathrm{NO}_{3}$ oxidation of SOA precursors is discussed. As the best match between modelled and observed OA was achieved with $R_{\text {sulf }}$, the analysis below will be restricted to this run.

\subsection{Comparison of modelled $\mathrm{NO}_{3}$ with measurements}

The modelled night-time $\mathrm{NO}_{3}$ concentrations can be compared with measurements from several different locations. Measurements made using a zenith sky spectrometer, were 


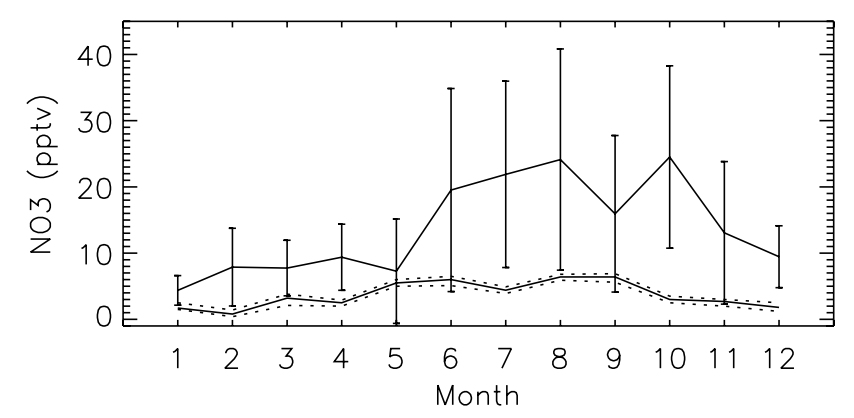

Fig. 6. Monthly mean night-time modelled $\mathrm{NO}_{3}$ mixing ratios (solid line, with vertical bars giving range of one standard deviation) and measurements made on Crete (lower line, with range of one standard deviation denoted by dotted lines, from Vrekoussis et al. 2006) between June 2001 and September 2003.

analysed by Allan et al. (2002) to calculate tropospheric profiles of $\mathrm{NO}_{3}$ during sunrise. Model night-time $\mathrm{NO}_{3}$ values were calculated for the same locations, during the same months (although the modelled values are from 2004, and the measurements in Allan et al. (2002) were carried out in 1997, 1999, and 2000 for Tenerife, Cape Grim and Norway respectively), and are compared with the measured values in Fig. 5. In all three panels of Fig. 5, the modelled values underestimate the measured values, however there is some overlap of the values within one standard deviation of modelled and measured means, especially in the case of Tenerife and Cape Grim, for the lower altitudes. Further, the model shows the increase in variability in values seen between the surface and about $2 \mathrm{~km}$ altitude at Cape Grim, as well as the pronounced gradient in $\mathrm{NO}_{3}$ concentration at Tenerife.

Night-time modelled $\mathrm{NO}_{3}$ mixing ratios were calculated and averaged for each month, for the model grid point near Finokalia on Crete, Greece. The results are compared with measurements made in the same area between June 2001 and September 2003 reported by Vrekoussis et al. (2006), in Fig. 6. The model overestimates $\mathrm{NO}_{3}$ for all months, and most of the measurements are at the lower end of the range of one standard deviation of the model results, except for May, when modelled and measured values are similar. The modelled values are elevated between about May and September, the same period for which an increase in the measured $\mathrm{NO}_{3}$ mixing ratio is seen. The reason for the overestimation is probably related to the model resolution, as emissions from mainland Greece, Libya and Turkey, as well as Crete itself are included in the model grid boxes surrounding the measurement point. Only emissions originating north of Crete are expected to affect the measurements (Vrekoussis et al., 2006), and these would be more diluted in reality than they are in the model, by the time they reach Crete.

The formation and loss of $\mathrm{NO}_{3}$ is closely linked with the chemistry of $\mathrm{NO}$ and $\mathrm{NO}_{2}$, therefore a further method of estimating a model's representation of $\mathrm{NO}_{3}$ is to compare the modelled abundance of these species with measurements. Model mixing ratios of $\mathrm{NO}$ and $\mathrm{NO}_{2}$ from Oslo CTM2 have been compared with measurements from Hohenpeissenberg in Germany, by Isaksen et al. (2005), where both the absolute values and the seasonal cycle have been shown to be well reproduced by the model. Tropospheric $\mathrm{NO}_{2}$ from a range of models is compared with measured values, retrieved from GOME data, by van Noije et al. (2006). The Oslo CTM2 is shown to have one of the higher $\mathrm{NO}_{2}$ values of the models, and to compare well with measured values.

\subsection{SOA production from $\mathrm{NO}_{3}$ oxidised hydrocarbons}

The fraction of annual mean SOA produced from precursors which were oxidised by $\mathrm{NO}_{3}$ is shown in Fig. 7, for the surface (Panel A) and for the total SOA column (Panel B), when the yield for $\beta$-pinene is used for $\mathrm{NO}_{3}$ oxidation of all class $\mathrm{I}-\mathrm{V}$ precursors. The effect of $\mathrm{NO}_{3}$ is much more evident at the surface, and near polluted regions, where emissions of nitrogen oxides coincide with high concentrations of terpenes. In some parts of Asia, up to $60 \%$ of the SOA at the surface consists of $\mathrm{NO}_{3}$ oxidation products. Similarly, high values are seen on the east coast of North America, as well as in southern Europe. The extremely low contribution of $\mathrm{NO}_{3}$ oxidation products around Papua New Guinea and parts of Indonesia are due to the formation of a large amount of SOA from isoprene oxidation products as, in the case of isoprene, only oxidation by $\mathrm{OH}$ can lead to SOA in this model. The influence of $\mathrm{NO}_{3}$ on the total SOA column, shown in panel B of Fig. 7, is much more uniform, with values over land in the Northern Hemisphere being between $30 \%$ and $45 \%$. Again, the fraction is highest over India and South Eastern China, and the east coast of North America.

The surface abundance of $\alpha$-pinene, $\mathrm{OH}, \mathrm{O}_{3}$ and $\mathrm{NO}_{3}$ has been plotted as a function of time of day (UTC) in Fig. 8, for approximately $32^{\circ} \mathrm{N}, 109^{\circ}-118^{\circ} \mathrm{E}$ (the area of high $\mathrm{NO}_{3}$ contribution to SOA in Fig. 7). In the bottom panel, the contribution of each oxidant to the condensible oxidation products is plotted. Local time is UTC $+8 \mathrm{~h}$. During the first part of the day, $\mathrm{NO}_{3}$ concentrations are low, however, as ozone increases later in the day, and as light levels decrease towards evening, the mixing ratios of $\mathrm{NO}_{3}$ increase. The values of $\mathrm{NO}_{3}$ in the afternoon appear rather high, however, observations of up to around $5 \mathrm{ppt}$ have been reported, in polluted air masses, $3 \mathrm{~h}$ before sunset (Geyer et al., 2003). The overlap of increasing $\mathrm{NO}_{3}$ with decreasing $\alpha$-pinene concentrations results in a large contribution of $\mathrm{NO}_{3}$ to the oxidation of $\alpha$-pinene, and because of the assumed yield of 1.0, this far outweighs oxidation by $\mathrm{OH}$ or $\mathrm{O}_{3}$ during the day. If a lower yield for $\mathrm{NO}_{3}$ oxidation of $\alpha$-pinene of 0.16 (Spittler et al., 2006) is used however, the contribution from $\mathrm{NO}_{3}$ oxidation is much lower (dash-dot line in Fig. 8).

Because of the rapid decrease in monoterpene emissions at sunset, and the rapid increase in $\mathrm{NO}_{3}$ concentrations as light levels decrease, the exact timing of these two processes is 


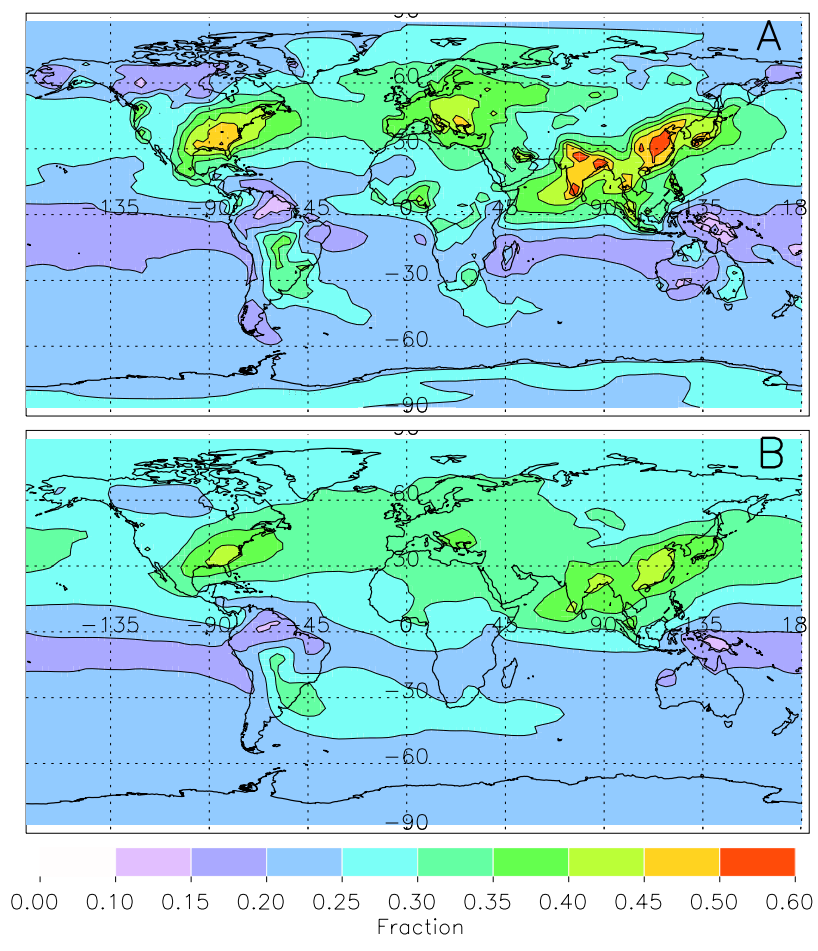

Fig. 7. The contribution of $\mathrm{NO}_{3}$ oxidation to (A) surface SOA and (B) total column SOA, when the condensible oxidation product yield of $\beta$-pinene is used for all class I-V precursors.

very important, and is a source of uncertainty in these model calculations.

A further model run was performed, where, instead of using the condensible product yield of the $\mathrm{NO}_{3}$ reaction with $\beta$-pinene for all species (i.e. 1.0), the more recently measured yield values of 0.16 for $\alpha$-pinene, and 0.4 for limonene were adopted (Spittler et al., 2006). A comparison of the contribution of $\mathrm{NO}_{3}$ oxidation to $\mathrm{SOA}$ formation between this run, and the one where the yield was 1.0 for all species is shown in Fig. 9. Panels A and C show the contribution for January, and $\mathrm{B}$ and $\mathrm{D}$ show the contribution for June. In panel $\mathrm{A}$, there is a large contribution of $\mathrm{NO}_{3}$ to $\mathrm{SOA}$ in the high northern latitudes due to the low light levels, however the actual concentration of SOA in this area is very low (see Fig. 1). In the model run where the yields from $\mathrm{NO}_{3}$ oxidation are lower, the contribution of $\mathrm{NO}_{3}$ to $\mathrm{SOA}$ is far lower, but still around $30 \%$ in areas such as South East Asia and the eastern USA. It was found by Spittler et al. (2006) that at a relative humidity of $20 \%$, the yield of SOA from $\mathrm{NO}_{3}$ oxidation of $\alpha$-pinene was further reduced, to about $4 \%$, however, a study by Bonn and Moorgat (2002) found that the presence of water vapour did not effect the particle size distributions observed during $\mathrm{NO}_{3}$ +limonene experiments.

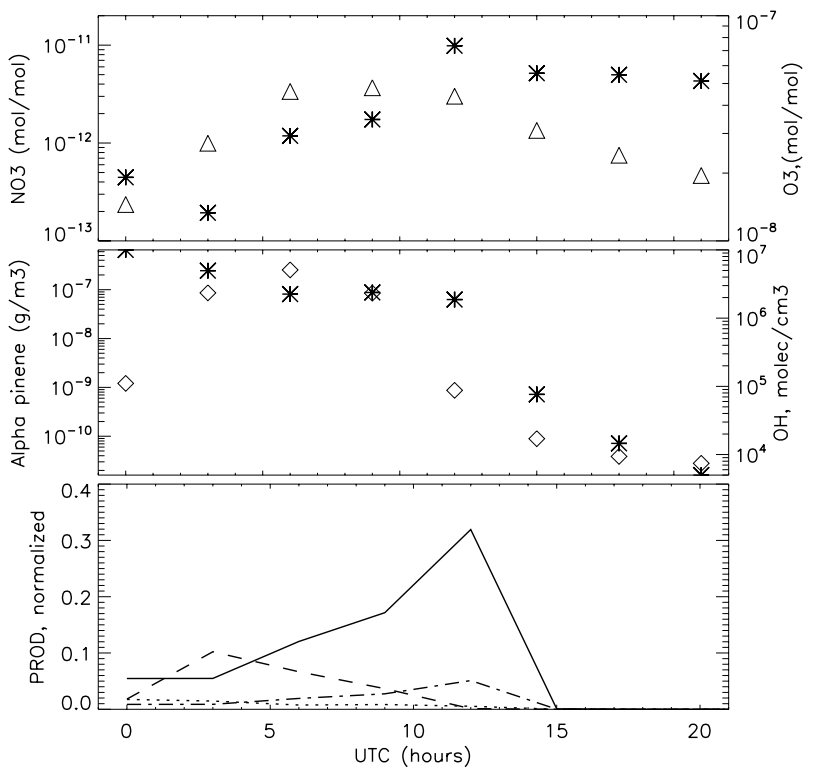

Fig. 8. Annual average surface mixing ratio of $\mathrm{NO}_{3}$ and $\mathrm{O}_{3}$ (top panel, stars and triangles respectively) and concentration of $\alpha$ pinene and $\mathrm{OH}$ (middle panel, stars and diamonds respectively), for approximately $32^{\circ} \mathrm{N}, 109^{\circ}-118^{\circ} \mathrm{E}$ (the area of high $\mathrm{NO}_{3}$ contribution to SOA in Fig. 7). The bottom panel shows the normalised production of condensible oxidation products from $\mathrm{OH}$ (dashed line), $\mathrm{O}_{3}$ (dotted line), $\mathrm{NO}_{3}$, assuming a yield of 1 (solid line). For comparison, production from $\mathrm{NO}_{3}$ assuming a yield of 0.16 (dash-dot line) is also included.

\section{Summary and conclusions}

A new module has been added to the Oslo CTM2, allowing the simulation of SOA formation, transport and loss. The calculated annual production $\left(55-69{\mathrm{Tg} \mathrm{yr}^{-1}}^{-1}\right.$ and burden $(0.52-0.70 \mathrm{Tg})$ of SOA are at the high end of the range of the results of previous model studies. The amount of SOA was increased by allowing semi-volatile species to partition to ammonium sulphate aerosol as well as to organic aerosol, and this lead to modelled OA values which were closer to the observed values than when only partitioning to pre-existing organic aerosol was allowed. Despite this improved agreement, the model still underestimates OA at most of the observation stations. Modelled OA values remain too low, especially in Europe, even when all semi-volatile species are partitioned to the aerosol phase, which suggests that the reason for the model underestimation of OA lies with the source of either POA or precursors of SOA, or both. Increasing the isoprene emissions in the model to bring them more in line with recent estimates will increase the SOA production, but this is unlikely to substantially reduce the underestimation of OA over Europe. The relative underestimation of measured values in winter is greater than in summer, and as POA is the dominant fraction of $\mathrm{OA}$ in winter, this suggests the 


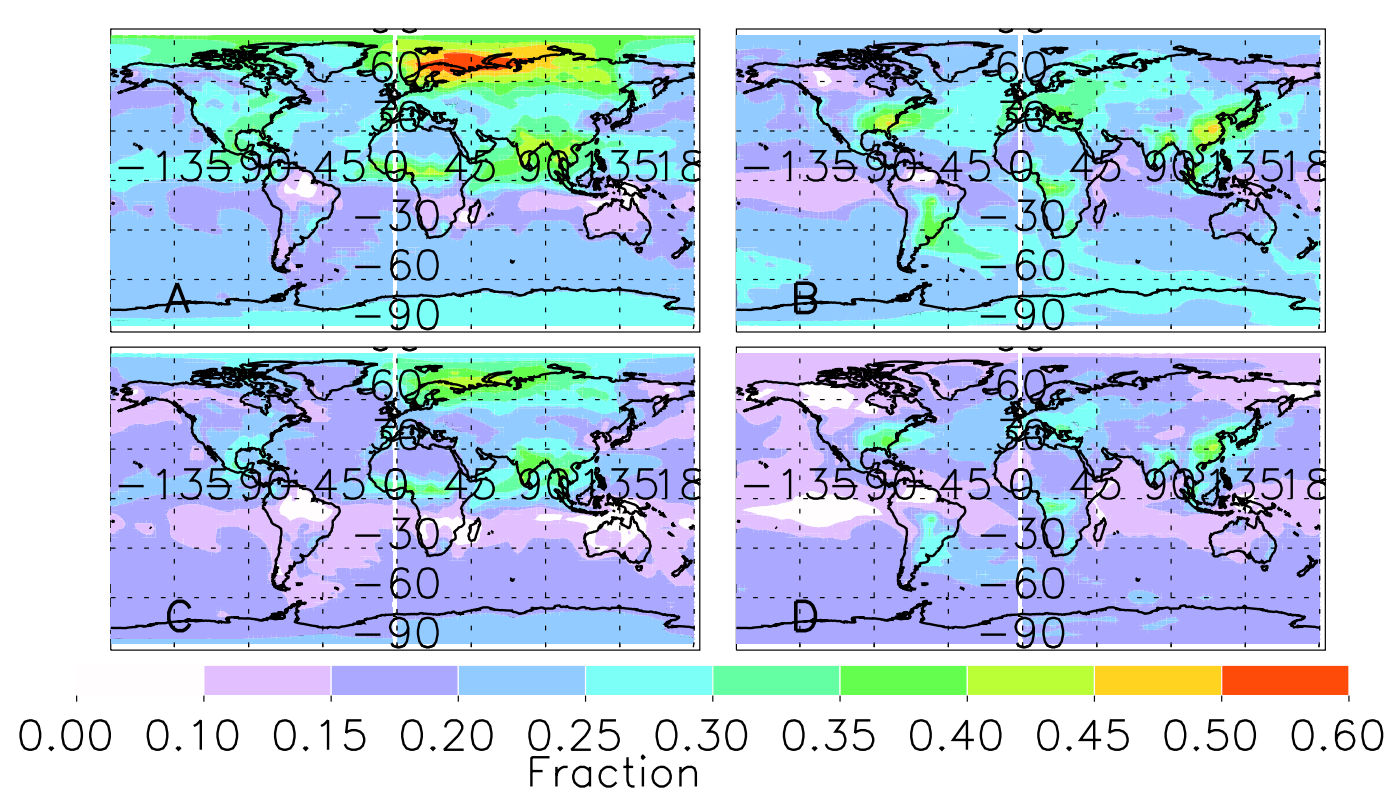

Fig. 9. Contribution of $\mathrm{NO}_{3}$ to the formation of SOA, for January (plots $\mathbf{A}$ and $\mathbf{C}$ ) and June (plots $\mathbf{B}$ and $\mathbf{D}$ ), where the condensible product yield from $\mathrm{NO}_{3}$ oxidation is set to 1.0 for precursor class $\mathrm{I}-\mathrm{V}$, (plots $\mathrm{A}$ and $\mathrm{B}$ ), and where the yield for oxidation of $\alpha$-pinene is set to 0.16 , and that for limonene to 0.4 (plots $\mathrm{C}$ and $\mathrm{D}$ ).

possibility of a too low POA source. In addition, as the modelled absolute increase in OA in summer is underestimated for most stations, an increase in SOA formation would improve the modelled summer values. Therefore, these results suggest that there may be unaccounted for sources of POA as well as SOA precursors, although a too-rapid removal of OA from the model atmosphere as well as uncertainty in the SOA yields from the oxidation of precursors may also contribute.

Further reduction of the uncertainties in emission estimates for POA, and SOA precursors would help reduce the uncertainties in modelling SOA formation. It is also apparent that similar SOA schemes can produce rather different results when combined with different global CTMs, due to differences in the calculation of wet deposition of SOA components as well as differences in advective and convective transport, and chemistry schemes.

The results of this study show a significantly higher contribution of $\mathrm{NO}_{3}$ oxidation products to the SOA burden than that found in previous studies. Regionally this contribution reached up to $60 \%$, and the global annual mean contribution was found to be about $27 \%$ when the yield of $\beta$-pinene is used for $\mathrm{NO}_{3}$ oxidation of all class I-V precursors. When yields of 0.16 for $\alpha$-pinene and 0.4 for limonene are used, this contribution reduces to about $21 \%$.

The contrast in the contribution of $\mathrm{NO}_{3}$ oxidation products to the SOA burden between regions with high anthropogenic emissions and relatively unpolluted regions, even when a reduced yield is used for $\mathrm{NO}_{3}$ oxidation, also highlights the importance of the anthropogenic influence on the oxidising capacity of the atmosphere, for regional SOA formation.

Many global models still treat SOA in a similar fashion to POA, i.e. as a direct emission, or do not include SOA at all (Textor et al., 2006). Representing SOA as a direct emission is too simplistic since the concentration of SOA has been shown, in both this and previous works, to depend upon a wide range of factors, such as emissions of precursors, oxidation compounds, and the loading of aerosols to which SOA may partition. In industrialised and biomass burning regions SOA accounts for an important fraction of the total OA. In biomass burning regions global models tend to underestimate the observed total aerosol optical depth (AOD) (Myhre et al., 2003; Kinne et al., 2006). Given the significant contribution of SOA to the total OA burden, a more realistic representation, in global aerosol models, of processes governing the SOA burden will reduce model underestimates of the AOD.

Acknowledgements. This work was supported by funding from BACCI (research unit on Biosphere-Aerosol-Cloud-ClimateInteractions), EUCAARI (European Integrated project on Aerosol Cloud Climate and Air Quality Interactions) as well as AerOzClim (Aerosols, Ozone and Climate, NFR project number 142050).

Edited by: S. Martin 


\section{References}

Ackerman, A. S., Toon, O. B., Stevens, D. E., Heymsfield, A. J., Ramanathan, V., and Welton, E. J.: Reduction of Tropical Cloudiness by Soot, Science, 288, 1042-1047, 2000.

Albrecht, B. A.: Aerosols, Cloud Microphysics, and Fractional Cloudiness, Science, 245, 1227-1230, 1989.

Allan, B. J., Plane, J. M. C., Coe, H., and Shillito, J.: Observations of $\mathrm{NO}_{3}$ concentration profiles in the troposphere, J. Geophys. Res., 107(D21), 4588 doi:10.1029/2002JD002112, 2002.

Atkinson, R.: Gas-phase tropospheric chemistry of organic compounds: a review , Atmospheric Environment Part A-General Topics, 24, 1-41, 1990.

Atkinson, R.: Gas-phase tropospheric chemistry of organic compounds, J. Phys. Chem. Ref. Data, Monogr., 2, 1-216, 1994.

Berglen, T. F., Berntsen, T. K., Isaksen, I. S. A., and Sundet, J. K.: A global model of the coupled sulfur/oxidant chemistry in the troposphere: The sulfur cycle, J. Geophys. Res., 109, D19310, doi:10.1029/2003JD003948, 2004.

Berntsen, T. K. and Isaksen, I. S. A.: A global three-dimensional chemical transport model for the troposphere 1. Model description and CO and ozone results, J. Geophys. Res., 102, 21239 21 280, doi:10.1029/97JD01140, 1997.

Bond, T. C., Streets, D. G., Yarber, K. F., Nelson, S. M., Woo, J.-H., and Klimont, Z.: A technology-based global inventory of black and organic carbon emissions from combustion, J. Geophys. Res.-Atmos., 109, D14203, doi:10.1029/2003JD003697, 2004.

Bonn, B. and Moorgat, G. K.: New particle formation during aand b-pinene oxidation by $\mathrm{O}_{3}, \mathrm{OH}$ and $\mathrm{NO}_{3}$, and the influence of water vapour: particle size distribution studies, Atmos. Chem. Phys., 2, 183-196, 2002,

http://www.atmos-chem-phys.net/2/183/2002/.

Brown, S. S., Osthoff, H. D., Stark, H., Dubé, W. P., Ryerson, T. B., Warneke, C., de Gouw, J. A., Wollny, A. G., Parrish, D. D., Fehsenfeld, F. C., and Ravishankara, A. R.: Aircraft observations of daytime $\mathrm{NO}_{3}$ and $\mathrm{N}_{2} \mathrm{O}_{5}$ and their implications for tropospheric chemistry, J. Photoch. Photobio. A, 176, 270-278, 2005.

Brunner, D., Staehelin, J., Rogers, H. L., Köhler, M. O., Pyle, J. A., Hauglustaine, D., Jourdain, L., Berntsen, T. K., Gauss, M., Isaksen, I. S. A., Meijer, E., van Velthoven, P., Pitari, G., Mancini, E., Grew, V., and Sausen, R.: An evaluation of the performance of chemistry transport models by comparison with research aircraft observations. Part 1: Concepts and overall model performance, Atmos. Chem. Phys., 3, 1609-1631, 2003, http://www.atmos-chem-phys.net/3/1609/2003/.

Chung, S. H. and Seinfeld, J. H.: Global distribution and climate forcing of carbonaceous aerosols, J. Geophys. Res.-Atmos., 107(D19), 4407, doi:10.1029/2001JD001397, 2002.

Cooke, W. F., Liousse, C., Cachier, H., and Feichter, J.: Construction of a $1^{\circ} \times 1^{\circ}$ fossil fuel emission data set for carbonaceous aerosol and implementation and radiative impact in the ECHAM4 model, J. Geophys. Res., 104(D18), 22 137-22 162, doi:10.1029/1999JD900187, 1999.

Derwent, R. G., Collins, W. J., Jenkin, M. E., Johnson, C. E., and Stevenson, D. S.: The Global Distribution of Secondary Particulate Matter in a 3-D Lagrangian Chemistry Transport Model, J. Atmos. Chem., 44, 57-95, 2003.

Dindorf, T., Kuhn, U., Ganzeveld, L., Schebeske, G., Ciccioli, P., Holzke, C., Köble, R., Seufert, G., and Kesselmeier, J.: Sig- nificant light and temperature dependent monoterpene emissions from European beech (Fagus sylvatica L.) and their potential impact on the European volatile organic compound budget, J. Geophys. Res.-Atmos., 111, D16305, doi:10.1029/2005JD006751, 2006.

Donahue, N. M., Robinson, A. L., Stanier, C. O., and Pandis, S. N.: Coupled partitioning, dilution and chemical aging of semivolatile organics, Environ. Sci. Technol., 40, 2635-2643, 2006.

Edney, E. O., Driscoll, D. J., Speer, R. E., Weathers, W. S., Kleindienst, T. E., Li, W., and Smith, D. F.: Impact of aerosol liquid water on secondary organic aerosol yields of irradiated toluene/propylene/ $\mathrm{NO}_{\mathrm{x}} /\left(\mathrm{NH}_{4}\right)_{2} \mathrm{SO}_{4}$ /air mixtures, Atmos. Environ., 34, 3907-3919, 2000.

Geyer, A., Alicke, B., Ackermann, R., Martinez, M., Harder, H., Brune, W., di Carlo, P., Williams, E., Jobson, T., Hall, S., Shetter, R., and Stutz, J.: Direct observations of daytime $\mathrm{NO}_{3}$ : Implications for urban boundary layer chemistry, J. Geophys. Res.Atmos., 108(D12), 4368, doi:10.1029/2002JD002967, 2003.

Granier, C., Lamarque, J. F., Mieville, A., Muller, J. F., Olivier, J., Orlando, J., Peters, J., Petron, G., Tyndall, G., and Wallens, S.: POET, a database of surface emissions of ozone precursors, available on internet at http://www.aero.jussieu.fr/projet/ ACCENT/POET.php, 2005.

Greenberg, J. P., Guenther, A., Harley, P., Otter, L., Veenendaal, E. M., Hewitt, C. N., James, A. E., and Owen, S. M.: Eddy flux and leaf-level measurements of biogenic VOC emissions from mopane woodland of Botswana, J. Geophys. Res.-Atmos., 108(D13), 8466, doi:10.1029/2002JD002317, 2003.

Griffin, R. J., Cocker, D. R., Seinfeld, J. H., and Dabdub, D.: Estimate of global atmospheric organic aerosol from oxidation of biogenic hydrocarbons, Geophys. Res. Lett., 26, 2721-2724, doi: 10.1029/1999GL900476, 1999a.

Griffin, R. J., Flagan, R. C., and Seinfeld, J. H.: Organic aerosol formation from the oxidation of biogenic hydrocarbons, J. Geophys. Res., 104, 3555-3568, doi:10.1029/1998JD100049, 1999b.

Guenther, A., Hewitt, C. N., Erickson, D., Fall, R., Geron, C., Graedel, T., Harley, P., Klinger, L., Lerdau, M., McKay, W. A., Pierce, T., Scholes, B., Steinbrecher, R., Tallamraju, R., Taylor, J., and Zimmerman, P.: A global model of natural volatile organic compound emissions, J. Geophys. Res., 100, 8873-8892, doi:10.1029/94JD02950, 1995.

Guenther, A., Karl, T., Harley, P., Wiedinmyer, C., Palmer, P. I., and Geron, C.: Estimates of global terrestrial isoprene emissions using MEGAN (Model of Emissions of Gases and Aerosols from Nature), Atmos. Chem. Phys., 6, 3181-3210, 2006, http://www.atmos-chem-phys.net/6/3181/2006/.

Han, J. S., Moon, K. J., Kong, B. J., Lee, S. J., Kim, J. E., and Kim, Y. J.: Seasonal variation of chemical composition in fine particles at Gosan, Korea, Environ. Monit. Assess., 107, 221-237, 2005.

Hansen, J., Sato, M., and Ruedy, R.: Radiative forcing and climate response, J. Geophys. Res., 102, 6831-6864, doi:10.1029/ 96JD03436, 1997.

Haywood, J. M. and Shine, K. P.: The effect of anthropogenic sulfate and soot aerosol on the clear sky planetary radiation budget, Geophys. Res. Lett., 22, 603-606, doi:10.1029/95GL00075, 1995.

Henze, D. K. and Seinfeld, J. H.: Global secondary organic aerosol from isoprene oxidation, Geophys. Res. Lett., 33, L09812, doi: 10.1029/2006GL025976, 2006. 
Hesstvedt, E., Hov, Ø., and Isaksen, I. S. A.: Quasi-Steady-State Approximations in Air-Pollution Modeling - Comparison of Two Numerical Schemes for Oxidant Prediction, Int. J. Chem. Kinet., 10, 971-994, 1978.

Hoffmann, T., Odum, J. R., Bowman, F., D.Collins, Klockow, D., Flagan, R. C., and Seinfeld, J. H.: Formation of Organic Aerosols from the Oxidation of Biogenic Hydrocarbons, J. Atmos. Chem., 26, 189-222, 1997.

Holtslag, A. A. M. and Ulden, A. P. V.: A Simple Scheme for Daytime Estimates of the Surface Fluxes from Routine Weather Data, J. Clim. Appl. Meteorol., 22, 517-529, 1983.

IPCC: Climate Change 2001: The Scientific Basis. Contribution of Working Group I to the Third Assessment Report of the Intergovernmental Panel on Climate Change, Cambridge University Press, Cambridge, United Kingdom and New York, NY, USA, 881 pp., 2001.

Isaksen, I. S. A., Zerefos, C., Kourtidis, K., Meleti, C., Dalsoren, S. B., Sundet, J. K., Grini, A., Zanis, P., and Balis, D.: Tropospheric ozone changes at unpolluted and semipolluted regions induced by stratospheric ozone changes, J. Geophys. Res., 110, D02302, doi:10.1029/2004JD004618, 2005.

Jones, A. P.: Indoor air quality and health, Atmos. Environ., 33, 4535-4564, 1999.

Kanakidou, M., Tsigaridis, K., Dentener, F. J., and Crutzen, P. J.: Human-activity-enhanced formation of organic aerosols by biogenic hydrocarbon oxidation, J. Geophys. Res., 105, 9243-9254, doi:10.1029/1999JD901148, 2000.

Kanakidou, M., Seinfeld, J. H., Pandis, S. N., Barnes, I., Dentener, F. J., Facchini, M. C., van Dingenen, R., Ervens, B., Nenes, A., Nielsen, C. J., Swietlicki, E., Putaud, J. P., Balkanski, Y., Fuzzi, S., Horth, J., Moortgat, G. K., Winterhalter, R., Myhre, C. E. L., Tsigaridis, K., Vignati, E., Stephanou, E. G., and Wilson, J.: Organic aerosol and global climate modelling: a review, Atmos. Chem. Phys., 5, 1053-1123, 2005,

http://www.atmos-chem-phys.net/5/1053/2005/.

Kesselmeier, J. and Staudt, M.: Biogenic Volatile Organic Compounds (VOC): An Overview on Emission, Physiology and Ecology, J. Atmos. Chem., 33, 23-88, 1999.

Kinne, S., Schulz, M., Textor, C., Guibert, S., Balkanski, Y., Bauer, S. E., Berntsen, T., Berglen, T. F., Boucher, O., Chin, M., Collins, W., Dentener, F., Diehl, T., Easter, R., Feichter, J., Fillmore, D., Ghan, S., Ginoux, P., Gong, S., Grini, A., Hendricks, J., Herzog, M., Horowitz, L., Isaksen, I., Iversen, T., Kirkevåg, A., Kloster, S., Koch, D., Kristjansson, J. E., Krol, M., Lauer, A., Lamarque, J. F., Lesins, G., Liu, X., Lohmann, U., Montanaro, V., Myhre, G., Penner, J., Pitari, G., Reddy, S., Seland, O., Stier, P., Takemura, T., and Tie, X.: An AeroCom initial assessment - optical properties in aerosol component modules of global models, Atmos. Chem. Phys., 6, 1815-1834, 2006,

http://www.atmos-chem-phys.net/6/1815/2006/.

Kleindienst, T. E., Smith, D. F., Li, W., Edney, E. O., Driscoll, D. J., Speer, R. E., and Weathers, W. S.: Secondary organic aerosol formation from the oxidation of aromatic hydrocarbons in the presence of dry submicron ammonium sulphate aerosol, Atmos. Environ., 33, 3669-3681, 1999.

Kroll, J. H., Chan, A. W. H., Ng, N. L., Flagan, R. C., and Seinfeld, J. H.: Reactions of semivolatile organics and their effects on secondary organic aerosol formation, Environ. Sci. Technol., 41, 3545-3550, 2007.
Kuhn, U., Rottenberger, S., Biesenthal, T., Wolf, A., Schebeske, G., Ciccioli, P., Brancaleoni, E., Frattoni, M., Tavares, T. M., and Kesselmeier, J.: Isoprene and monoterpene emissions of Amazônian tree species during the wet season: Direct and indirect investigations on controlling environmental functions, J. Geophys. Res.-Atmos., 107(D20), 8069, doi:10.1029/ 2000JD000303, 2002.

Lack, D. A., Tie, X. X., Bofinger, N. D., Wiegand, A. N., and Madronich, S.: Seasonal variability of secondary organic aerosol: A global modeling study, J. Geophys. Res.-Atmos., 109, D03203, doi:10.1029/2003JD003418, 2004.

Lathière, J., Hauglustaine, D. A., Friend, A. D., de NobletDucoudré, N., Viovy, N., and Folberth, G. A.: Impact of climate variability and land use changes on global biogenic volatile organic compound emissions, Atmos. Chem. Phys., 6, 2129-2146, 2006, http://www.atmos-chem-phys.net/6/2129/2006/.

Liousse, C., Penner, J. E., Chuang, C., Walton, J. J., Eddleman, H., and Cachier, H.: A global three-dimensional model study of carbonaceous aerosols, J. Geophys. Res., 101, 19411-19432, doi:10.1029/95JD03426, 1996.

Maria, S. F., Russell, L. M., Gilles, M. K., and Myneni, S. C. B.: Organic Aerosol Growth Mechanisms and Their Climate-Forcing Implications, Science, 306, 1921-1924, doi:10.1126/science. 1103491, 2004.

Myhre, G., Berntsen, T. K., Haywood, J. M., Sundet, J. K., Holben, B. N., Johnsrud, M., and Stordal, F.: Modelling the solar radiative impact of aerosols from biomass burning during the Southern African Regional Science Initiative (SAFARI-2000) experiment, J. Geophys. Res.-Atmos., 108(D13), 8501, doi: 10.1029/2002JD002313, 2003.

Myhre, G., Bellouin, N., Berglen, T. F., Berntsen, T. K., Boucher, O., Grini, A., Isaksen, I. S. A., Johnsrud, M., Mishchenko, M. I., Stordal, F., and Tanré, D.: Comparison of the radiative properties and direct radiative effect of aerosols from a global aerosol model and remote sensing data over ocean, Tellus B, 59, 115-129, doi: 10.1111/j.1600-0889.2006.00226.x, 2007.

Northcross, A. L. and Jang, M.: Heterogeneous SOA yield from ozonlysis of monoterpenes in the presence of inorganic acid, Atmos. Environ., 41, 1483-1493, 2007.

Odum, J. R., Jungkamp, T. P. W., Griffin, R. J., Flagan, R. C., and Seinfeld, J. H.: The Atmospheric Aerosol-Forming Potential of Whole Gasoline Vapor, Science, 276, 96-99, 1997.

Ostro, B. and Chestnut, L.: Assessing the health benifits of reducing particulate matter air pollution in the United States, Environ. Res., 76, 94-106, 1998.

Otter, L., Guenther, A., Wiedinmyer, C., Fleming, G., Harley, P., and Greenberg, J.: Spatial and temporal variations in biogenic volatile organic compound emissions for Africa south of the equator, Journal of Geophysical Research (Atmospheres), 108(D13), 8505, doi:10.1029/2002JD002609, 2003.

Penkett, S. A., Blake, N. J., Lightman, P., Marsh, A. R. W., Anwyl, P., and Butcher, G.: The seasonal variation of nonmethane hydrocarbons in the free troposphere over the North Atlantic Ocean - Possible evidence for extensive reaction of hydrocarbons with the nitrate radical, J. Geophys. Res., 98, 2865-2885, 1993.

Penner, J. E., Chuang, C. C., and Grant, K.: Climate forcing by carbonaceous and sulfate aerosols, Clim. Dynam., 14, 839-851, 1998. 
Pun, B. K., Wu, S.-Y., Seigneur, C., Seinfeld, J. H., Griffin, R. J., and Pandis, S. N.: Uncertainties in Modeling Secondary Organic Aerosols: Three-Dimensional Modeling Studies in Nashville/Western Tennessee, Environ. Sci. Technol., 37, 3647-3661, 2003.

Puxbaum, H., Rendl, J., Allabashi, R., Otter, L., and Scholes, M. C.: Mass balance of the atmospheric aerosol in a South African subtropical savanna (Nylsvley, May 1997), J. Geophys. Res., 105, 20 697-20 706, doi:10.1029/2000JD900306, 2000.

Robinson, A. L., Donahue, N. M., Shrivastava, M. K., Weitkamp, E. A., Sage, A. M., Grieshop, A. P., Lane, T. E., Pierce, J. R., and Pandis, S. N.: Rethinking Organic Aerosols: Semivolatile Emissions and Photochemical Aging, Science, 315, 1259-1262, doi:10.1126/science.1133061, 2007.

Schulz, M., Textor, C., Kinne, S., Balkanski, Y., Bauer, S., Berntsen, T., Berglen, T., Boucher, O., Dentener, F., Guibert, S., Isaksen, I. S. A., Iversen, T., Koch, D., Kirkevåg, A., Liu, X., Montanaro, V., Myhre, G., Penner, J. E., Pitari, G., Reddy, S., Seland, Ø., Stier, P., and Takemura, T.: Radiative forcing by aerosols as derived from the AeroCom present-day and pre-industrial simulations, Atmos. Chem. Phys., 6, 5225-5246, 2006 ,

http://www.atmos-chem-phys.net/6/5225/2006/.

Shrivastava, M. K., Lipsky, E. M., Stanier, C. O., and Robinson, A. L.: Modeling semivolatile organic aerosol mass emissions from combustion systems, Environ. Sci. Technol., 40, 26712677, 2006.

S.Moukhtar, Bessagnet, B., Rouil, L., and Simon, V.: Monoterpene emissions from Beech (Fagus sylvatica) in a French forest and impact on secondary pollutants formation at regional scale, Atmos. Environ., 39, 3535-3547, 2005.

Spittler, M., Barnes, I., Bejan, I., Brockmann, K. J., Benter, T., and Wirtz, K.: Reactions of $\mathrm{NO}_{3}$ radicals with limonene and $\alpha$ pinene: Product and SOA formation, Atmos. Environ., 40, 116127, 2006.

Takami, A., Miyoshi, T., Shimono, A., and Hatakeyama, S.: Chemical composition of fine aerosol measured by AMS at Fukue Island, Japan during APEX period, Atmos. Environ., 39, 49134924, 1995.

Textor, C., Schulz, M., Guibert, S., Kinne, S., Balkanski, Y., Bauer, S., Berntsen, T., Berglen, T., Boucher, O., Chin, M., Dentener, F., Diehl, T., Easter, R., Feichter, H., Fillmore, D., Ghan, S., Ginoux, P., Gong, S., Grini, A., Hendricks, J., Horowitz, L., Huang, P., Isaksen, I., Iversen, I., Kloster, S., Koch, D., Kirkevåg, A., Kristjansson, J. E., Krol, M., Lauer, A., Lamarque, J. F., Liu, X., Montanaro, V., Myhre, G., Penner, J., Pitari, G., Reddy, S., Seland, Ø., Stier, P., Takemura, T., and Tie, X.: Analysis and quantification of the diversities of aerosol life cycles within AeroCom, Atmos. Chem. Phys., 6, 1777-1813, 2006,

http://www.atmos-chem-phys.net/6/1777/2006/.

Tsigaridis, K. and Kanakidou, M.: Global modelling of secondary organic aerosol in the troposphere: A sensitivity analysis, Atmos. Chem. Phys., 3, 2879-2929, 2003,

http://www.atmos-chem-phys.net/3/2879/2003/.

Tsigaridis, K., Lathière, J., Kanakidou, M., and Hauglustaine, D. A.: Naturally driven variability in the global secondary organic aerosol over a decade, Atmos. Chem. Phys., 5, 1891-1904, 2005 ,

http://www.atmos-chem-phys.net/5/1891/2005/.
Turpin, B. J. and Lim, H.-J.: Species contributions to PM2.5 mass concentrations: revisiting common assumptions for estimating organic mass, Aerosol Sci. Technol., 35, 602-610, doi:10.1080/ 02786820119445, 2001.

Twomey, S.: The Nuclei of Natural Cloud Formation Part II: The Supersaturation in Natural Clouds and the Variation of Cloud Droplet Concentration, Geofisica pura e applicata, 43, 243-249, 1959.

Twomey, S.: The Influence of Pollution on the Shortwave Albedo of Clouds, J. Atmos. Sci., 34, 1149-1152, 1977.

van der Werf, G. R., Randerson, J. T., Giglio, L., Collatz, G. J., Kasibhatla, P. S., and Arellano, Jr., A. F.: Interannual variability in global biomass burning emissions from 1997 to 2004, Atmos. Chem. Phys., 6, 3423-3441, 2006,

http://www.atmos-chem-phys.net/6/3423/2006/.

van Noije, T. P. C., Eskes, H. J., Dentener, F. J., Stevenson, D. S., Ellingsen, K., Schultz, M. G., Wild, O., Amann, M., Atherton, C. S., Bergmann, D. J., Bey, I., Boersma, K. F., Butler, T., Cofala, J., Drevet, J., Fiore, A. M., Gauss, M., Hauglustaine, D. A., Horowitz, L. W., Isaksen, I. S. A., Krol, M. C., Lamarque, J.F., Lawrence, M. G., Martin, R. V., Montanaro, V., Müller, J.-F., Pitari, G., Prather, M. J., Pyle, J. A., Richter, A., Rodriguez, J. M., Savage, N. H., Strahan, S. E., Sudo, K., Szopa, S., and van Roozendael, M.: Multi-model ensemble simulations of tropospheric $\mathrm{NO}_{2}$ compared with GOME retrievals for the year 2000, Atmos. Chem. Phys., 6, 2943-2979, 2006, http://www.atmos-chem-phys.net/6/2943/2006/.

Virkkula, A., Teinilã, K., Hillamo, R., V.-M.Kerminen, Saarikoski, S., Aurela, M., J.Viidanoja, Paatero, J., Koponen, I. K., and Kulmala, M.: Chemical composition of boundary layer aerosol over the Atlantic Ocean and at an Antarctic site, Atmos. Chem. Phys., 6, 3407-3421, 2006, http://www.atmos-chem-phys.net/6/3407/2006/.

Volkamer, R., Jimenez, J. L., San Martini, F., Dzepina, K., Zhang, Q., Salcedo, D., Molina, L. T., Worsnop, D. R., and Molina, M. J.: Secondary organic aerosol formation from anthropogenic air pollution: Rapid and higher than expected, Geophys. Res. Lett., 33, L17811, doi:10.1029/2006GL026899, 2006.

Vrekoussis, M., Kanakidou, M., Mihalopoulos, N., Crutzen, P. J., Lelieveld, J., Perner, D., Berresheim, H., and Baboukas, E.: Role of the $\mathrm{NO}_{3}$ radicals in oxidation processes in the eastern Mediterranean troposphere during the MINOS campaign, Atmos. Chem. Phys., 4, 169-182, 2004,

http://www.atmos-chem-phys.net/4/169/2004/.

Vrekoussis, M., Liakakou, E., Mihalopoulos, N., Kanakidou, M., Crutzen, P. J., and Lelieveld, J.: Formation of $\mathrm{HNO}_{3}$ and $\mathrm{NO}_{3}^{-}$in the anthropogenically-influenced eastern Mediterranean marine boundary layer, Geophys. Res. Lett., 33, L05811, doi:10.1029/ 2005GL025069, 2006.

Yang, H., Yu, J. Z., Ho, S. S. H., Xu, J., W.-S.Wu, Wan, C. H., Wang, X., Wang, X., and Wang, L.: The chemical composition of inorganic and carbonaceous materials in $\mathrm{PM}_{2.5}$ in Nanjing, China, Atmos. Environ., 39, 3735-3749, 2005.

Yttri, K. E., Aas, W., Bjerke, A., Ceburnis, D., Dye, C., Emblico, L., Facchini, M. C., Forster, C., Hanssen, J. E., Hansson, H. C., Jennings, S. G., Maenhaut, W., Putaud, J. P., , and Tørseth, K.: Elemental and organic carbon in $\mathrm{PM}_{10}$ : a one year measurement campaign within the European Monitoring and Evaluation Programme EMEP, Atmos. Chem. Phys. Discuss., 7, 3859-3899, 
2007 ,

http://www.atmos-chem-phys-discuss.net/7/3859/2007/.

Zhang, Q., Worsnop, D. R., Canagaratna, M. R., and Jimenez, J. L.: Hydrocarbon-like and oxygenated organic aerosols in Pittsburgh: insights into sources and processes of organic aerosols, Atmos. Chem. Phys., 5, 3289-3311, 2005,

http://www.atmos-chem-phys.net/5/3289/2005/. 